\title{
Raven Rock Mountain Complex Site C, MD Archaeological Phase I Survey
}

Carey L. Baxter, Adam D. Smith, and Ellen R. Hartman

August 2019

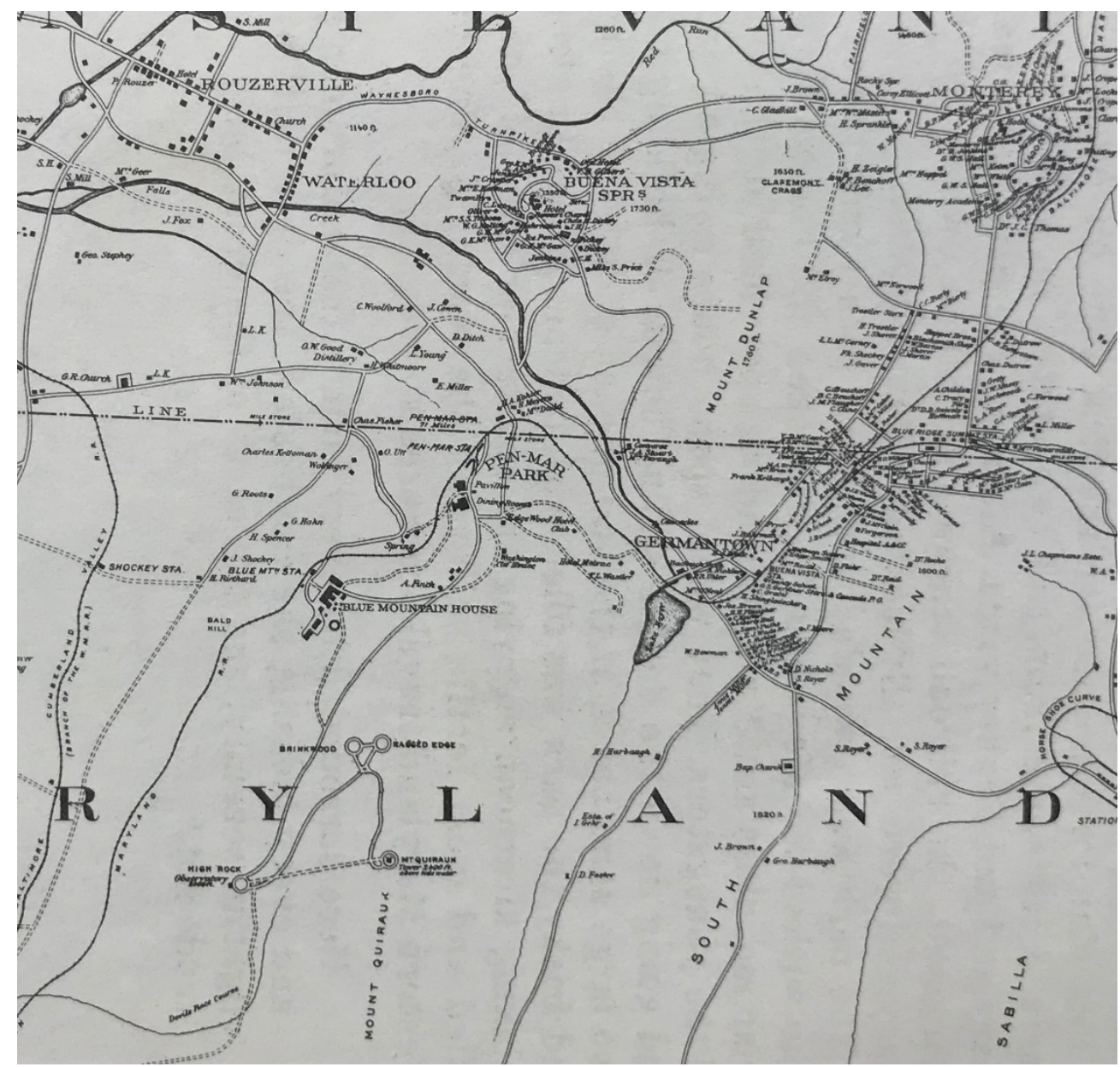


The U.S. Army Engineer Research and Development Center (ERDC) solves the nation's toughest engineering and environmental challenges. ERDC develops innovative solutions in civil and military engineering, geospatial sciences, water resources, and environmental sciences for the Army, the Department of Defense, civilian agencies, and our nation's public good. Find out more at www.erdc.usace.army.mil.

To search for other technical reports published by ERDC, visit the ERDC online library at http://acwc.sdp.sirsi.net/client/default.

Cover Photo: Portion of Atlas of Adams County Pennsylvania, 1872 (Adams County Historical Society). 


\section{Raven Rock Mountain Complex Site C, MD Archaeological Phase I Survey}

Carey L. Baxter, Adam D. Smith, and Ellen R. Hartman

U.S. Army Engineer Research and Development Center (ERDC)

Construction Engineering Research Laboratory (CERL)

2902 Newmark Dr.

Champaign, IL 61824

Final Technical Report (TR)

Approved for public release; distribution is unlimited.

Prepared for Environmental Safety, Health, and Industrial Hygiene Department Raven Rock Mountain Complex

Fairfield, PA 17320

Under Project 469449, "Work for RRMC" 


\section{Abstract}

The U.S. Congress codified the National Historic Preservation Act of 1966 (NHPA), the nation's most effective cultural resources legislation to date, mostly through establishing the National Register of Historic Places (NRHP). The NHPA requires federal agencies to address their cultural resources, which are defined as any prehistoric or historic district, site, building, structure, or object. Section 110 of the NHPA requires federal agencies to inventory and evaluate their cultural resources, and Section 106 requires them to determine the effect of federal undertakings on those potentially eligible for the NRHP.

In 2017, ERDC-CERL was tasked with conducting a Phase I Archaeological survey of Raven Rock Mountain Complex Site C in Maryland. RRMC is a division of the Washington Headquarters Service (WHS). No comprehensive Phase I Survey had been conducted at this site previously. This report documents that survey effort. In consultation with the Maryland State Historic Preservation Officer (SHPO), this work fulfills the Section 110 responsibilities for the archaeology at Site C.

DISCLAIMER: The contents of this report are not to be used for advertising, publication, or promotional purposes. Citation of trade names does not constitute an official endorsement or approval of the use of such commercial products. All product names and trademarks cited are the property of their respective owners. The findings of this report are not to be construed as an official Department of the Army position unless so designated by other authorized documents.

DESTROY THIS REPORT WHEN NO LONGER NEEDED. DO NOT RETURN IT TO THE ORIGINATOR. 


\section{Contents}

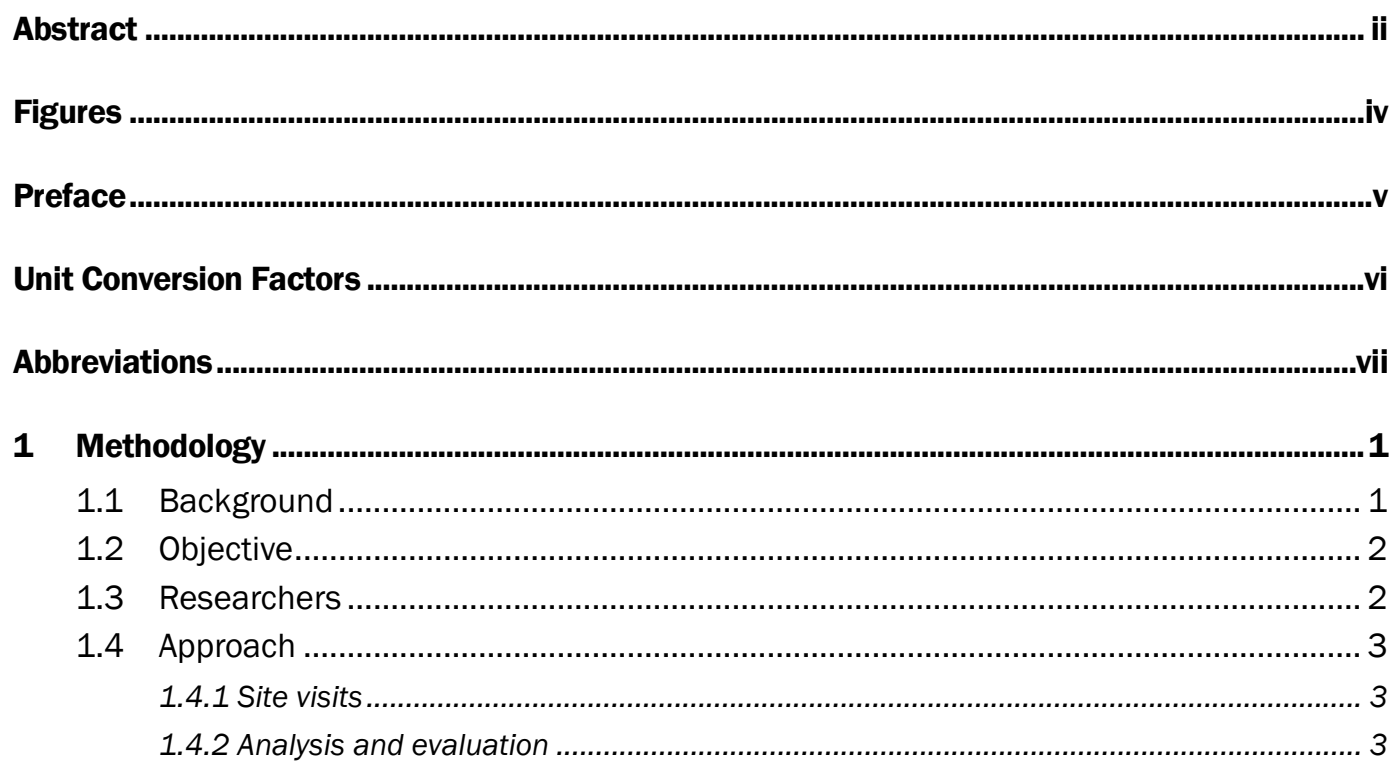

2 History and Setting of Raven Rock Mountain Complex Site C, Maryland ............................... 5

2.1 Environmental Setting ...................................................................................... 5

2.2 Prehistoric Context................................................................................................. 6

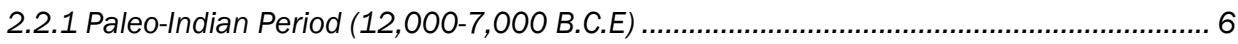

2.2.2 The Archaic Period (7000 B.C.E - 1000 B.C.E).............................................................. 7

2.2.3 The Woodland Period (1000 B.C.E to European Contact)................................................ 8

2.3 Historic Context.................................................................................................. 9

3 Phase I Survey of Raven Rock Mountain Complex Site C, Maryland......................................29

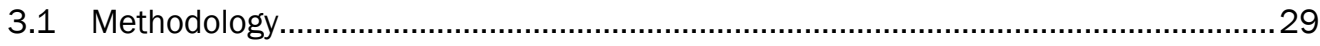

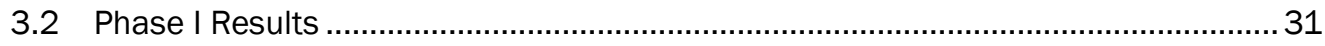

4 Determination of Eligibility for the NRHP..........................................................................35

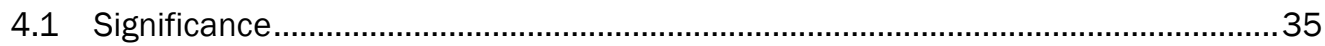

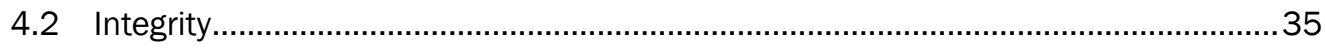

4.3 Findings at Raven Rock Mountain Complex Site C ................................................36

$5 \quad$ Final Recommendations for Eligibility and Conclusion ....................................................39

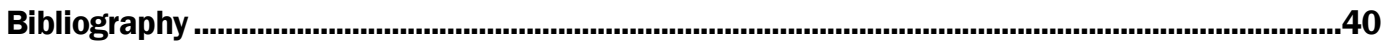

Report Documentation Page (SF 298) .............................................................................................43 


\section{Figures}

1 Location of Raven Rock Mountain Complex Site C, in north-central

Maryland

2 Region Surrounding Site C on Mount Quirauk (ERDC-CERL 2019)

3 Prehistoric sites in the region of Site $\mathrm{C}$ from data from the Maryland State Survey (ERDC-CERL, 2018)

$4 \quad$ Map of the Western Maryland and Pennsylvania, 1751. Project area indicated by red circle..

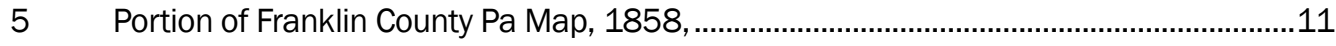

$6 \quad$ The Devil's Race Course...............................................................................................13

71859 Map of the project area showing no roads or structure in what became Pen Mar.

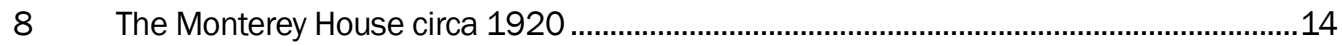

$9 \quad$ The Battle of Monterey Pass ...........................................................................................15

10 Undated map (probably before 1903) showing proximity of Pen Mar to Buena Vista and Monterey ..........................................................................................18

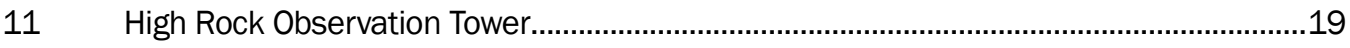

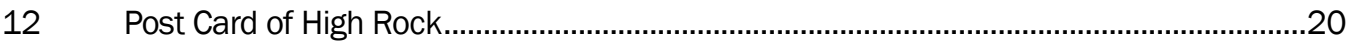

13 Period illustrations of Pen Mar and High Rock ...............................................................21

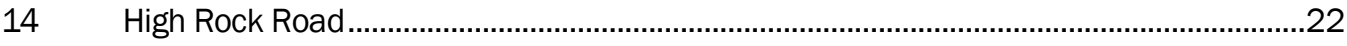

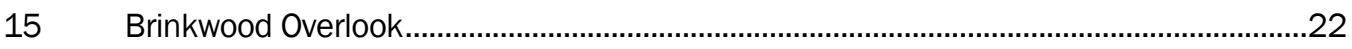

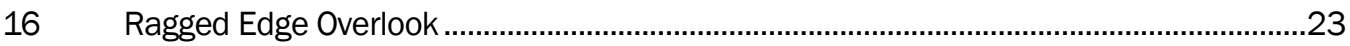

$17 \quad$ Post card of Tip Top Tower .................................................................................................23

18 Tip Top Tower at the Summit of Mount Quirauk .................................................................24

191909 U.S. Geological Survey (USGS) Quadrangle map showing the summit of Mount Quirauk.................................................................................................25

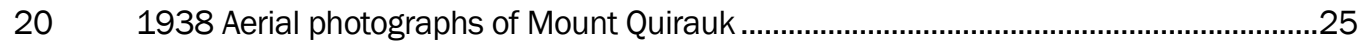

$21 \quad 1942$ Smithfield, Maryland Quadrangle Map...................................................................26

221952 Aerial of Mount Quirauk and Camp Ritchie .................................................................26

231953 Smithfield Quadrangle Map of Mount Quirauk.......................................................2

$24 \quad 1983$ USGS Quad Map of Mount Quirauk.............................................................................28

$25 \quad$ Area covered by Phase I survey (ERDC-CERL, 2018) .......................................................33

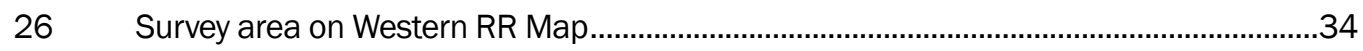




\section{Preface}

This study was conducted for the Cultural Resources Program, Environmental, Safety, and Health Division, of Raven Rock Mountain Complex, under Project 469449, "Work for RRMC." The technical monitor was Donna Swauger, Environmental Protection Specialist, Raven Rock Mountain Complex.

The work was performed by the Land and Heritage Conservation Branch (CNC) of the Installations Divisions (CN), U.S. Army Engineer Research and Development Center - Construction Engineering Research Laboratory (ERDC-CERL). At the time of publication, Dr. Michael L. Hargrave was Chief, CEERD-CNC, and Ms. Michelle J. Hanson was Chief, CEERD-CN. The Deputy Director of ERDC-CERL was Dr. Kirankumar Topudurti, and the Director was Dr. Lance D. Hansen.

COL Ivan P. Beckman was the Commander of ERDC, and Dr. David W. Pittman was the Director. 


\section{Unit Conversion Factors}

\begin{tabular}{|l|l|l|}
\hline Multiply & By & To Obtain \\
\hline acres & $4,046.873$ & square meters \\
\hline feet & 0.3048 & meters \\
\hline inches & 0.0254 & meters \\
\hline miles (U.S. statute) & $1,609.347$ & meters \\
\hline square feet & 0.09290304 & square meters \\
\hline yards & 0.9144 & meters \\
\hline
\end{tabular}




\section{Abbreviations}

$\begin{array}{ll}\text { Term } & \text { Definition } \\ \text { BCP } & \text { BRAC Cleanup Plan } \\ \text { BRAC } & \text { Base Realignment and Closure } \\ \text { CERL } & \text { Construction Engineering Research Laboratory } \\ \text { DoD } & \text { U.S. Department of Defense } \\ \text { DoDI } & \text { Department of Defense Instruction } \\ \text { ERDC } & \text { U.S. Army Engineer Research and Development Center } \\ \text { ERDC-CERL } & \text { Engineer Research and Development Center, Construction Engineering } \\ & \text { Research Laboratory } \\ \text { GIS } & \text { Geographic Information System } \\ \text { GPS } & \text { Global Positioning System } \\ \text { ICRMP } & \text { Integrated Cultural Resources Management Plan } \\ \text { IPUMS } & \text { Integrated Public Use Microdata Series } \\ \text { MHT } & \text { Maryland Historic Trust } \\ \text { ND } & \text { No Date } \\ \text { NHPA } & \text { National Historic Preservation Act of 1966 } \\ \text { NPS } & \text { National Park Service } \\ \text { NRCS } & \text { Natural Resources Conservation Service } \\ \text { NRHP } & \text { National Register of Historic Places } \\ \text { OMB } & \text { Office of Management and Budget } \\ \text { RRMC } & \text { Raven Rock Mountain Complex } \\ \text { SHPO } & \text { State Historic Preservation Office } \\ \text { TR } & \text { Technical Report } \\ \text { USDA } & \text { U.S. Department of Agriculture } \\ \text { USGS } & \text { U.S. Geological Survey } \\ \text { UTM } & \text { Universal Transverse Mercator } \\ \text { WHS } & \text { Washington Headquarters Service } \\ & \end{array}$


THIS PAGE INTENTIONALLY LEFT BLANK 


\section{Methodology}

\subsection{Background}

The U.S. Congress codified the National Historic Preservation Act of 1966 (NHPA), the nation's most effective cultural resources legislation to date, to provide guidelines and requirements for identifying tangible elements of our nation's past. This legislative requirement was met through creation of the National Register of Historic Places (NRHP). Contained within this piece of legislation (NHPA Sections 110 and 106) are requirements for federal agencies to address their cultural resources, defined as any prehistoric or historic district, site, building, structure, or object. Section 110 requires federal agencies to inventory and evaluate their cultural resources. Section 106 requires the determination of effect of federal undertakings on properties deemed eligible or potentially eligible for the NRHP.

Raven Rock Mountain Complex (RRMC) is a U.S. Department of Defense (DoD) facility located at Raven Rock Mountain near Blue Ridge Summit in Adams County, Pennsylvania (Figure 1). The U.S. Army began construction of the facility in 1951, which opened in 1953. RRMC is a division of the Washington Headquarters Service (WHS).

Figure 1. Location of Raven Rock Mountain Complex Site C, in north-central Maryland.

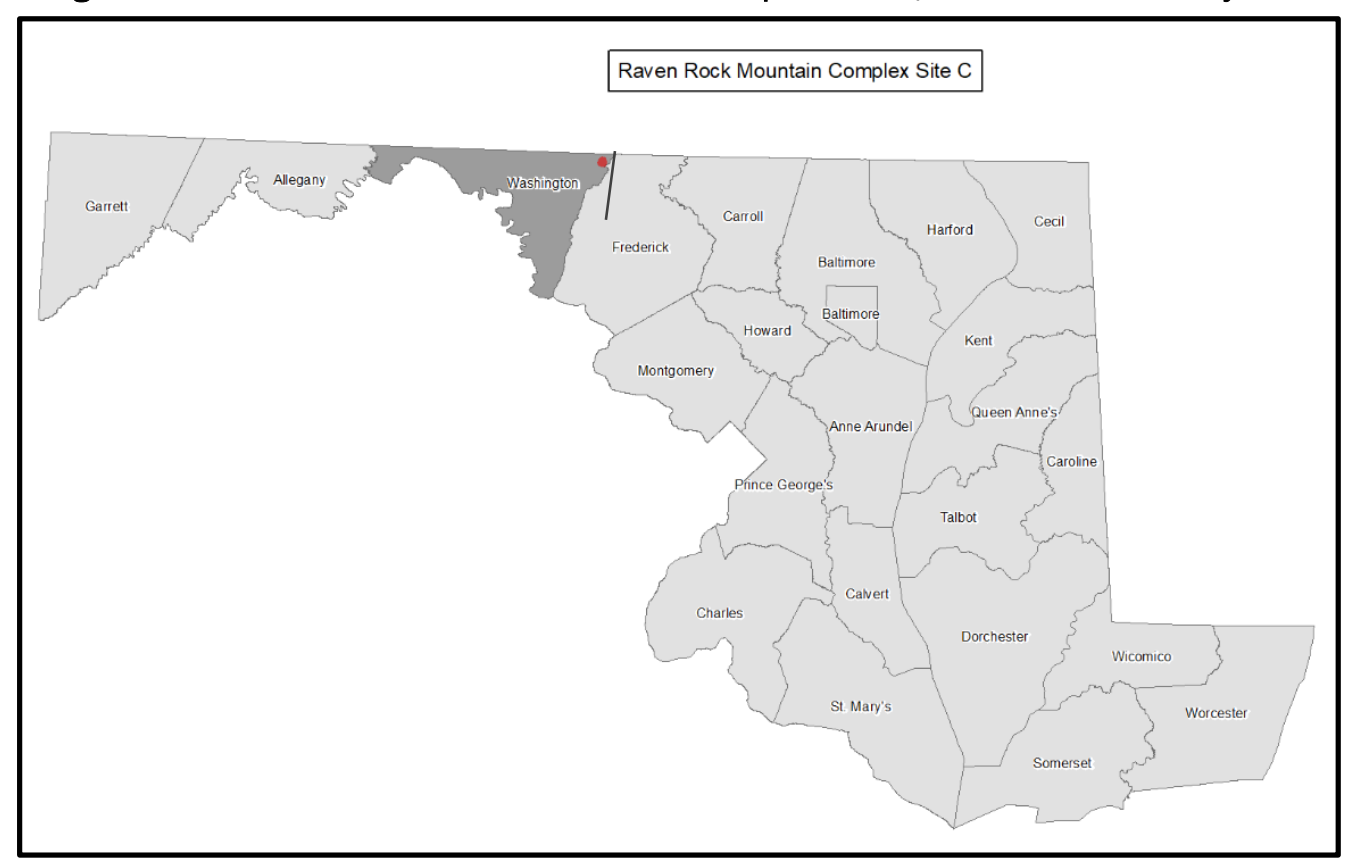

Source: ERDC-CERL (2018). 
There are DoD-specific mandates regarding historic properties that supplement and support Section 106 and Section 110. Department of Defense Instruction (DoDI) 4715.16 requires places under DoD control to develop Integrated Cultural Resource Management Plans (ICRMPs). As part of the ICRMP and pursuant to the NHPA, DoD facilities are required to identify and manage historic properties on their lands.

An archaeological Phase I survey is designed to address the Section 110 requirements of the NHPA by assessing the general nature of the archaeological resources present on the site. It should cover the entire property and is intended to locate and identify all archaeological resources as well as potential buried surfaces and areas of previous disturbances within the property area. If archaeological resources are identified, then additional surveys should be conducted to determine the integrity and significance of each site and to make a determination of eligibility to the NHPA.

In 2018, ERDC-CERL was tasked with conducting a Phase I Archaeological survey of Raven Rock Mountain Complex Site C. No comprehensive Phase I Survey had been conducted at this site previously. This final report provides historic context for the project area and documents the Phase I Archaeological Survey conducted at the installation.

\subsection{Objective}

The objective of this work was to conduct a Phase I Archaeological survey of Raven Rock Mountain Complex Site C and to document that survey effort.

\subsection{Researchers}

This project was conducted by the U.S. Army Corps of Engineers, Engineering Research Development Center, Construction and Engineering Research Laboratory (ERDC-CERL) in Champaign, Illinois. The research team included Carey L. Baxter, Bachelor of Arts as lead archaeologist, with 18 years of experience in prehistoric and historic archaeology; Adam D. Smith, Master of Architecture, as project manager, with 20 years of experience in military architectural history; and Ellen R. Hartman, Master of Landscape Architecture, as research and field assistant, with 10 years of experience. 


\subsection{Approach}

\subsubsection{Site visits}

\subsubsection{RRMC}

ERDC-CERL personnel made three trips to Site R and Site C at RRMC to inventory historic materials, conduct archival research at local and regional archives and to look at features at Site C in December 2017, February 2018, and March 2018. During those weeks, team members conducted site revisits and re-evaluations of all archaeological resources at Site C.

\subsubsection{Archival repositories}

ERDC-CERL researchers conducted a review of literature, archival repositories, and online resources related to the Raven Rock and Mt. Quirauk area before RRMC was established in 1951. The following places were contacted and/or searched:

- NRHP listings and nomination forms, available through Universal Resource Locator (URL): https://www.nps.gov/Nr/publications/index.htm;

- Historic drawings, maps, photographs, and information provided by the Environmental, Safety, and Health Division and the Geographic Information System (GIS) office at RRMC;

- Maryland State Historic Preservation Office, available through URL: https://mht.maryland.gov/secure/synthesis/SynthesisSearch.aspx;

- United States Library of Congress Maps Division, available through URL: https://www.loc.gov/maps/collections/?st=gallery;

- The Integrated Public Use Microdata Series (IPUMS) U.S Census Data collections, available through URL: https://usa/ipums.org/usa/index.shtml;

- Adams County Historical Society, Gettysburg, Pennsylvania;

- Adams County Public Library, Gettysburg, Pennsylvania;

- Blue Ridge Summit Free Library, Blue Ridge Summit, Pennsylvania;

- Alexander Hamilton Memorial Free Library, Waynesboro, Pennsylvania;

- Smithsburg Library, Smithsburg, Maryland;

- Western Maryland Room, Washington County Free Library, Hagerstown, Maryland.

\subsubsection{Analysis and evaluation}

After initial research was completed, the team analyzed the gathered information. Archival information and field information were integrated 
throughout the course of the project. The information available was contained in text documents, photographs, and historic maps. Using archival sources, the research team extracted relevant historical information. The material was then combined to tell the story in both text and images.

A cultural resource can retain or lose its historic integrity, meaning that it either does or does not convey its historic significance. From this evaluation process, a recommendation of eligibility for listing on the NRHP was made. The evaluation adhered to the following guidelines:

- National Register Bulletin \#15, How to Apply the National Register Criteria for Evaluation (NPS 1997a);

- National Register Bulletin \#16A, How to Complete the National Register Registration Form (NPS 1997b);

- National Register Bulletin, How to Prepare National Historic Landmark Nominations (NPS 1999);

- The Secretary of the Interior's Standards for the Treatment of Historic Properties with Guidelines for the Treatment of Cultural Landscapes (Grimmer 2017). 


\section{History and Setting of Raven Rock Mountain Complex Site C, Maryland}

This chapter summarizes the history of Mount Quirauk, Maryland before acquisition of the property by the U.S. government.

\subsection{Environmental Setting}

Site C is located on Mount Quirauk in the north eastern corner or Washington County, Maryland (Figure 1). The mountain is the highest point on South Mountain. South Mountain is a single ridge 70 miles in length located at the northern end of the Blue Ridge Mountain Range. It forms the western edge of the coastal Piedmont region and the eastern boundary of the Cumberland Valley (Figure 2). Mount Quirauk summit elevation is $2,145 \mathrm{ft}$ above sea level. The mountain, which was originally called Mount Misery, was renamed Mount Quirauk when the area was developed as a tourist location (Schlotterbeck 1977).

Site C sits atop the summit of Mount Quirauk with the landscape consisting primarily of exposed stones of Cambrian and Ordovician limestone and dolomite as well as Lower Cambrian quartzite and limestone. Seventyfive percent of the project area have slopes greater than 25 degrees. Less than $10 \%$ of the project area, located at the summit of the mountain, has slopes of less than 10 degrees. Large areas of unweathered and weathered bedrock are exposed throughout the project area, most notably at the summit where the slopes are the shallowest. Soil types at Site C are of the Dekalb-Rock Outcrop and Dekalb-Bagton-Rock Outcrop series (USDA NRCS 2018). This soil series consists of well-drained cobbly loam that are typically moderately deep and well developed (USDA 2003); however, the erosion on the extreme slopes of the mountain, combined with the fact that there are no depositional factors on the exposed summit within the project area, have impeded any type of soil development. Soils probes in undisturbed soils demonstrated an extremely rocky soil with an averaged depth of $15 \mathrm{~cm}$ to bedrock. These soil types and slopes are unsuitable for agricultural or habitation use and are best suited for forest habitats.

Undisturbed areas of the project area are covered in dense broadleaf forest. The shallow soils in the area, combined with the prevalence of surface bedrock, have limited the quantity of undergrowth typically seen in surrounding forest areas. There is no natural water source on the mountain 
summit. The presence of larger forms of wildlife and birdlife are limited by the lack of forage and water on the mountain. Evidence of deer was seen at the lower elevations of the project area near High Rock observation point and deer stands were observed on private property off the road approximately one-half to two-thirds the distance between High Rock and the summit but no traces of deer were seen at the project area at the summit.

Figure 2. Region Surrounding Site C on Mount Quirauk (ERDC-CERL 2019).

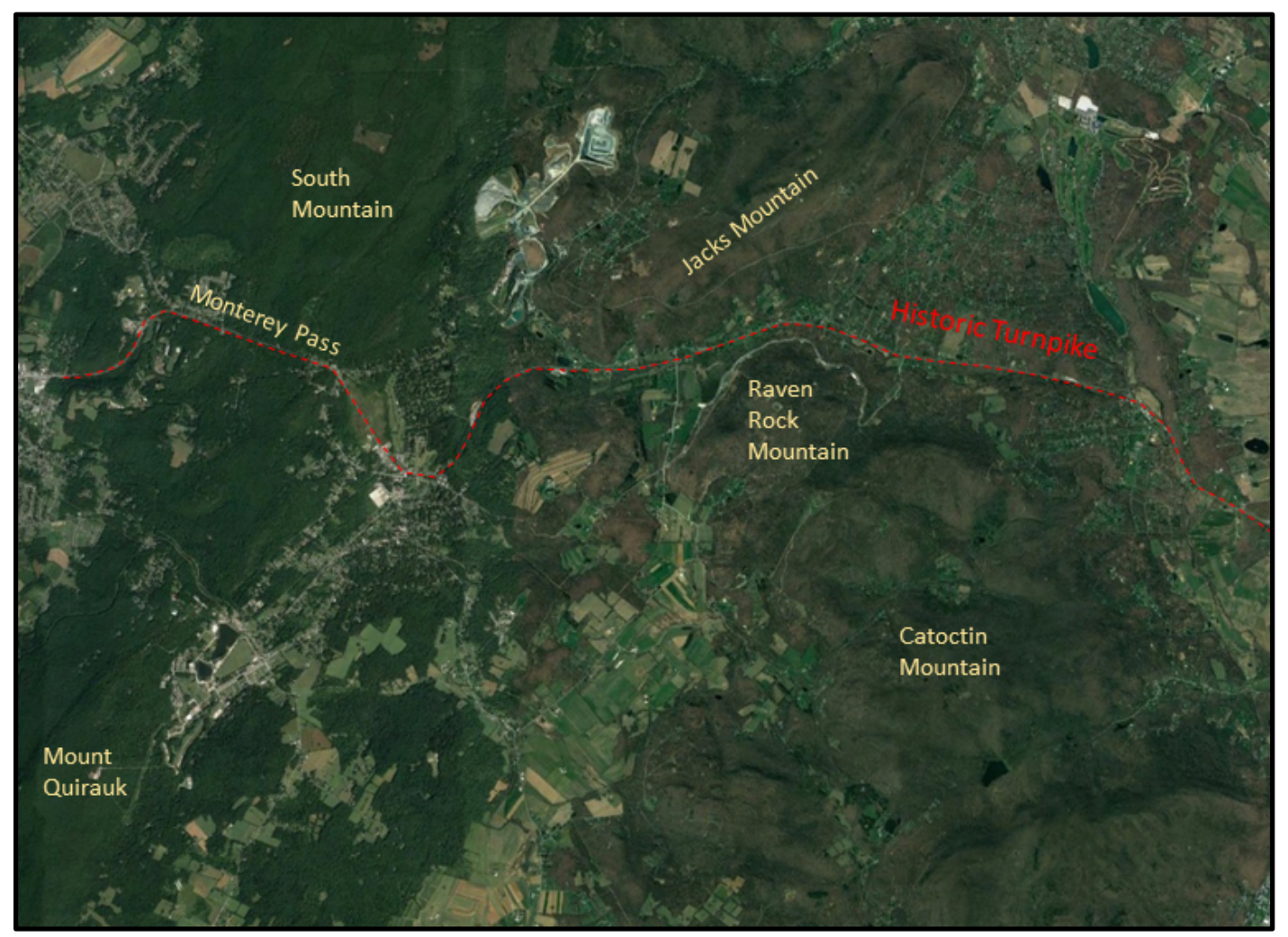

\subsection{Prehistoric Context}

\subsubsection{Paleo-Indian Period (12,000-7,000 B.C.E)}

Paleo-Indian peoples were non-sedentary hunter-gatherers. This period corresponds to the end of the Pleistocene ice ages. The project area consisted of tundra-like climate and vegetation with the addition of conifer trees (Gardner 1974, Hay et al. 1988, Baltimore District 2001). Mega fauna still existed during this time period but was not common in the Pennsylvania/Maryland project region (Gardner 1974, Sanders et al. 1996) and subsistence was based on deer, caribou, small game, and wild plants. Paleo-Indian artifact assemblages consist almost exclusively of stone tools with occasional bone tools and fragments also preserved. Pottery had not been developed and preservation of flora or faunal material is very rare for objects of 
that age. Stone tools may be chipped or groundstone in manufacture and are often distinguished by high levels of skill and quality in production.

The Maryland Historic Trust (MHT), the state's historic preservation office, reports a small number of sites in Washington County and adjoining Frederick County that possibly date to the Paleo-Indian period (MASP 2018). These sites are associated with rock shelters in the southern portions of the two counties and not in the general region of the project area.

\subsubsection{The Archaic Period (7000 B.C.E - 1000 B.C.E)}

The Archaic Period is differentiated from the Paleo-Indian by the retreat of the glaciers and the current climate and environments (Hatch et al. 1985). The environment changed from one characterized by tundra and coniferous forest to one dominated by deciduous forests. The extinction of the mega fauna was offset by the emergence of a wider variety of flora and fauna that could be exploited as food stuffs. The new subsistence species included a wider variety of fish, shellfish, and migratory bird species. The new subsistence opportunities and patterns led to a corresponding expansion in settlement patterns and types. Sites from the Archaic Period are found in a larger variety of terrains and settings, where longer periods of site occupation are seen. The archaic artifact assemblage is still dominated by lithic technologies. The variety of tool types greatly expands and becomes more regionally specific in kind and style.

The MHT reports two archaic sites in proximity to Site C. Both occur at the base of the east side of Mount Quirauk (Figure 3) (MASP 2018). Site 18FR661 was described as a lithic scatter of about equal numbers of quartz and rhyolite flakes. One rhyolite projectile point base was dated to the archaic period but could not be further attributed to a sub-period or phase. All materials in the lithic scatter were sourced from the immediate area of the site and no subsurface features were found. Site 18 FR66o is also a lithic scatter, mostly of rhyolite flakes. One late archaic and one late woodland point were the only diagnostics recovered from the site. Like FR 661 all material was sourced from the immediate area and no subsurface features were found. A third site (site 18FR659) was found slightly more distant from Site $\mathrm{C}$ and to the northeast. This site was also a lithic scatter, this time consisting of only quartz flakes. No diagnostics or subsurface features were found at this site. The lack of any subsurface features, the relatively small amount of artifacts from each site (50-100 artifacts), the local source of all materials recovered from the sites, and the small number of artifact 
types indicate sites of brief occupation, are typical of what one would expect from a temporary camp instead of a base camp or village.

Figure 3. Prehistoric sites in the region of Site $C$ from data from the Maryland State Survey (ERDC-CERL, 2018).

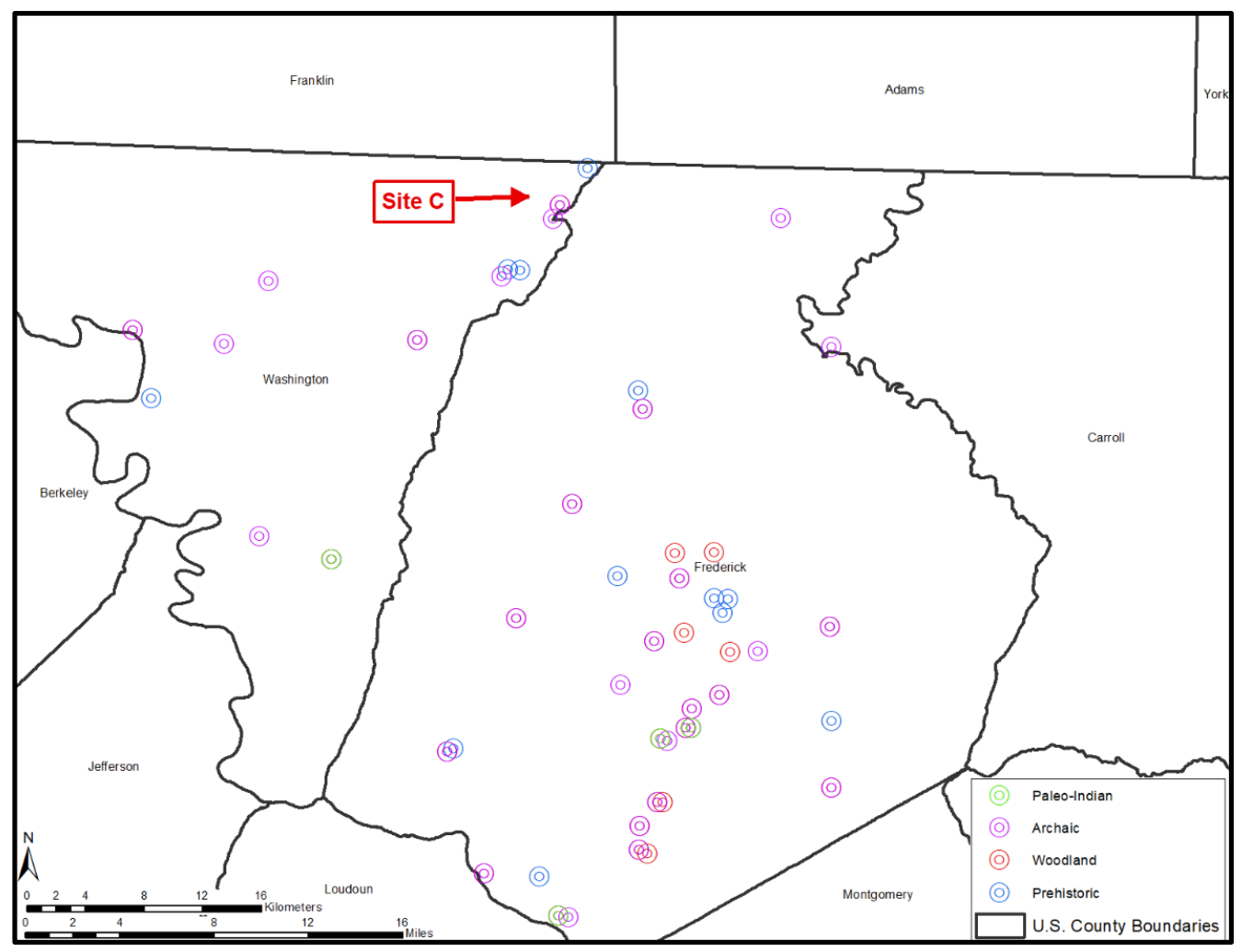

\subsubsection{The Woodland Period (1000 B.C.E to European Contact)}

The Woodland Period is distinguished from the Archaic by the development of horticulture and ceramic technologies (Baltimore District 2001). Typical flora used by woodland people are beans, squash, gourds, medicinal plants, and some maize. Village settlement patterns emerge as the peoples became more settled and began to tend and guard their fields. Diverse camps, however, continued to be occupied for hunting and resource procurement activities. The Woodland artifact assemblage is a mixture of lithic and ceramic material. Tool types become more generalized and multiuse and the level of refinement in tool design and execution generally decreased as each individual was expected to become proficient in a wider variety of manufacturing technologies. Craft specialization is typically not seen in the Woodland period. 
With the exception of the late Woodland projectile point recovered from site 18FR660, MHT does not report Woodland sites in the general proximity of the project area. This may be a result of the rocky soil not being conducive to agriculture. The area was likely still used for hunting, trapping, and lithic procurement. These kinds of sites, however, would have been ephemeral in nature and are difficult to detect today.

\subsection{Historic Context}

The Colony of Maryland was established in 1632 via royal charter issued to Cecilius Calvert, $2^{\text {nd }}$ Baron Baltimore with the first settlers arriving two years later (Andrews 1929). Most of the early colonization focused on the eastern coast. Early $18^{\text {th }}$ century European settlement of what became Washington County consisted primarily of scattered subsistence farmsteads in addition to hunting and trapping activities (Williams 1906). This changed in March, 1732 when Charles Calvert, $5^{\text {th }}$ Baron Baltimore and Proprietary Governor of the Province of Maryland, publically advertised incentives of rent and tax relief to people willing to settle the western parts of the colony (Williams 1906). The first land title in the county was issued to Charles Friend in 1739 for property near modern day Williamsport (Williams 1906). Hagerstown was established in 1762 and became the county seat when Washington County was sub-divided from Frederick County in 1776 (Andrews 1929, Williams 1906). Much of the early settlement was focused on agriculturally productive land in the southern and central portions of the county; the project area remained sparsely populated.

Washington County saw some military action during the French and Indian War. Braddock's 1755 expedition of 1500 men, including George Washington, passed from Fort Cumberland, Maryland to take Fort Duquesne, Pennsylvania in the southern portion of the county near Boonsboro along the path of State Highway ALT 40A (Andrews 1929, Williams 1906). While there is little evidence of skirmishes in the project area, some settlers fled the region for more settled areas to the east (Williams 1906). The downward trend in the population, however, reversed after the end of the hostilities. One of the lasting effects of this war was the abandonment of the area by much of the Native American population in the region (Williams 1906) for lands further west.

The history of the Site $\mathrm{C}$ area is closely tied to the hospitality industries since at least the mid- $18^{\text {th }}$ century when the Great Wagon Road was established in 1748 (Fry and Jefferson 1751) (Figure 4). The road was 435 miles 
long, starting in Philadelphia and passed through the gap north of South Mountain (north of Site C) near what today is the town of Blue Ridge Summit. This pass, which is called Monterey Pass today, was historically called Nicholas's Gap and Willoughby's Gap (McClellon ND) and was one of the principle transportation routes from New England to the southern and western colonies (Rouse 1995). It was easier to travel through the Gap than to ascend over mountains so several other roads converged to the north of Site C. These include the Chambersburg-Baltimore Road, the Georgetown/Middleton Valley Road, and the McDowell/Smith Mill Road (McClellon ND) although period maps generally only show the Great Wagon Road. Blue Ridge Summit was the high point in the roads through the pass and travelers often needed to stop there on their journey to rest their horses. Local farmers would offer the travelers a place to stay for the night. These accommodations generally consisted of a share of whatever the family was eating and a place on the floor to sleep and fodder for the animals. The farmers did not charge for their hospitality but guests were expected to provide something as a thank you gift.

The farmers in the region could not support themselves without supplemental income due to the poor soil. This income was gained by formalizing the hospitality system by opening up inns that charged patrons for food and lodging (see Figure 5). The first mention of Blue Ridge Summit was in 1775 in the diary of Phillip Vickers Fithian, a traveling minister (McClellon ND) who described staying at an unnamed log cabin inn at Nicholson's Gap. Taverns in the region with known names included Maguire's Place and Bubbling Springs Tavern. 
Figure 4. Map of the Western Maryland and Pennsylvania, 1751. Project area indicated by red circle.

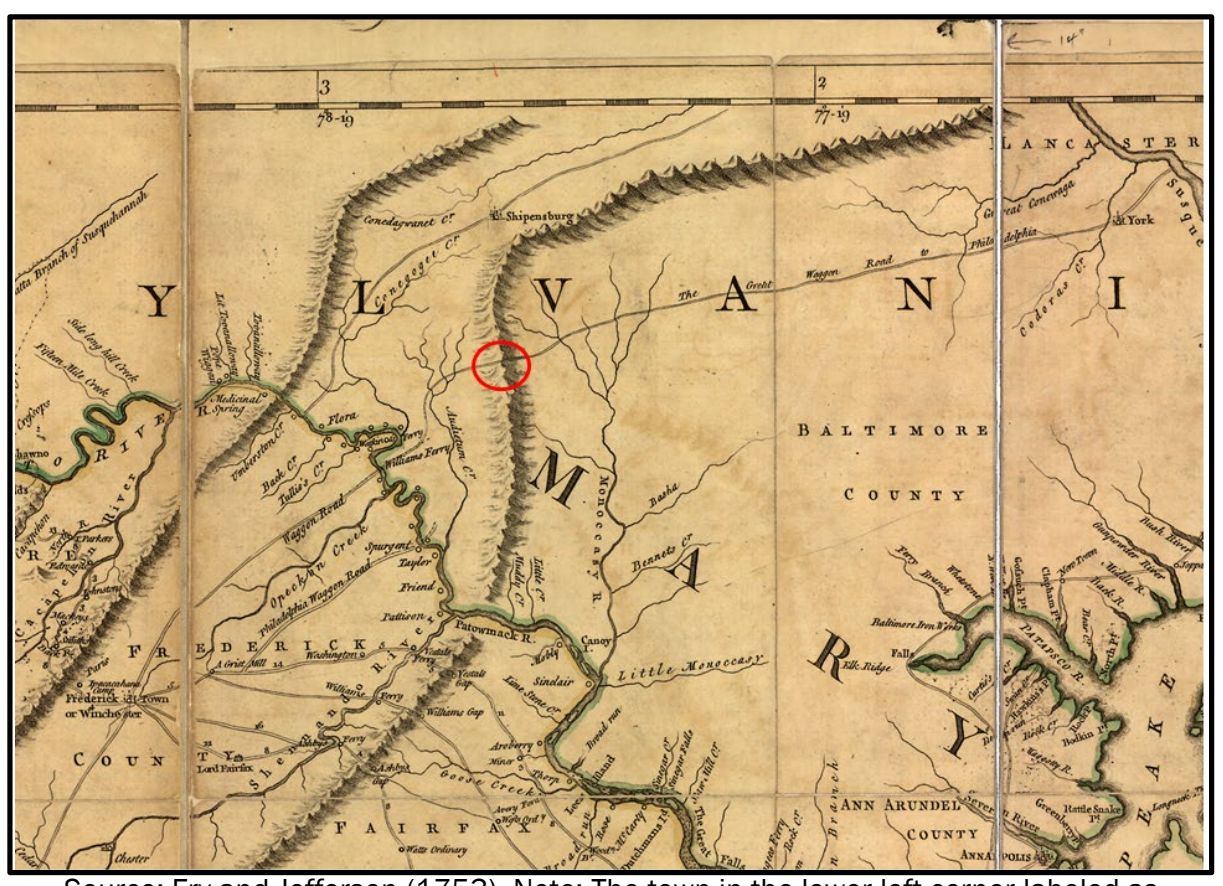

Source: Fry and Jefferson (1753). Note: The town in the lower left corner labeled as "Frederick or Winchester" is Winchester, MD.

Figure 5. Portion of Franklin County Pa Map, 1858,

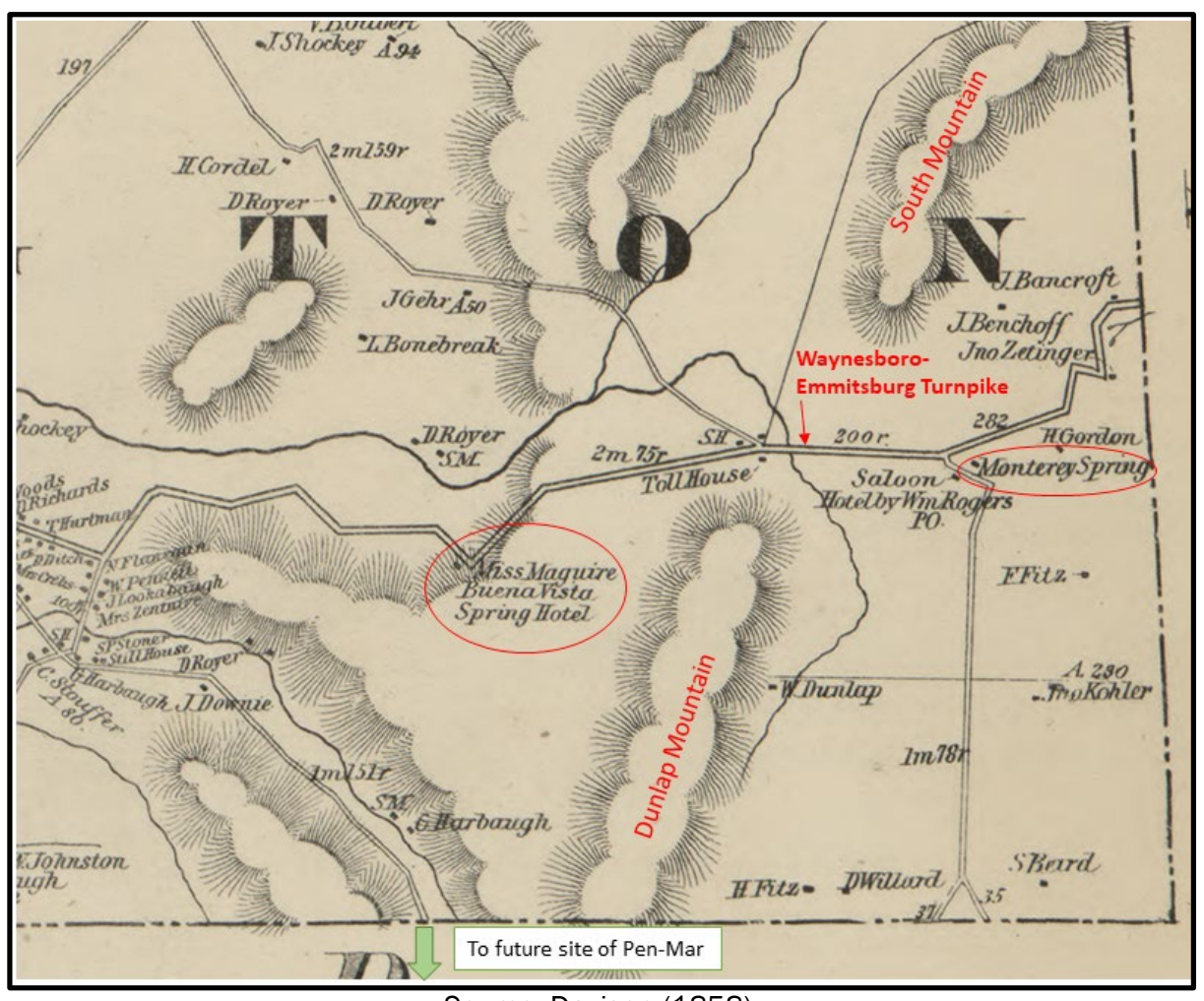

Source: Davison (1858). 
Maguire's Place was significant for further development of the region. The inn was built in an area that was completely unsuited for any farming but was located near a natural spring, close to the Devil's Race Course (McClellon ND). The Devil's Race Course ${ }^{1}$ was a shallow river that was so completely covered with rock and small boulders that the water could not be seen but could be heard when you were walking over the rock field (Schlotterbeck 1977, Strain 1993) (Figure 6). Most of the Race Course was destroyed in 1939 when it was used as fill for the construction of Highway 16. The placement of the inn near the Race Course is the first recorded instance of the area's unique geology being used as a draw for a particular inn. This inn was replaced in 1821 by a larger inn on the other side of the road that had a better view and facilities that more closely fit the description of 'hotel' (McClellon ND). The original inn was kept as an auxiliary structure for the new building.

There was a significant decline in the amount of traffic on the turnpikes in the 1840 s and 1850 s as the railroads and the Chesapeake and Ohio Canal were established. This decline was offset by the rise of health tourism. The area started to market itself as a location that offered clean mountain air and natural springs where people could go to 'take the water'. McGuire's Inn continued to be the leader in this trend. To help market the establishment, the inn repeatedly changed its name from Maguire's Inn to Cold Springs, Beautiful View, Buena Vista Springs and finally the Buena Vista Spring Hotel (McClellon ND). Development of the area, however had not extended up the mountain (Figure 7). Mount Misery (the original name of Mount Quirauk) was largely undeveloped (Figure 7) although some accounts mention people hiking up to a promontory (presumably High Rock) (McClellon ND, Schlotterbeck 1977).

\footnotetext{
1 The exact location of the Devil's Race Course is not clear. Early 19th century references place the feature in or near the present day town of Monterey PA, on the southern flanks of South Mountain. Early $20^{\text {th }}$ century maps of Pen Mar Park and current signage at High Rock Observation Point locate the Devil's Race Course on the SW side of Mount Quirauk near the current town of Edgemont MD. On-line map queries locate the Race Course on the east flank of South Mountain north of the town of Charmian, PA. It is probable that there were several places where one could visit the Race Course that waxed and waned in popularity at different historic periods. The portion of the Race Course that was destroyed in 1939 is almost certainly the portion that ran through or near the town of Monterey as this is also the course of Rt. 16.
} 
Figure 6. The Devil's Race Course.

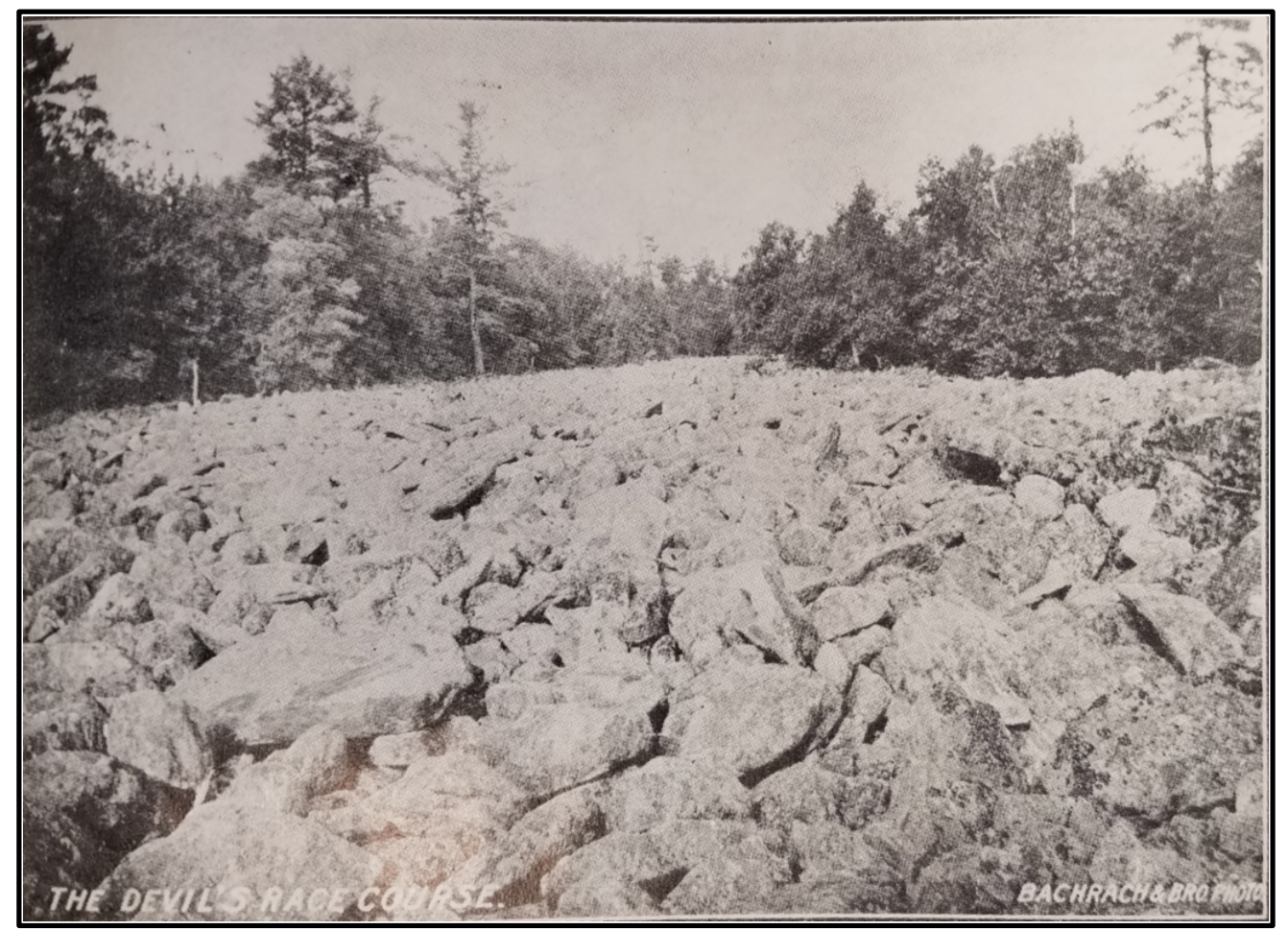

Source: Spitzer (1986).

Figure 7. 1859 Map of the project area showing no roads or structure in what became Pen Mar.

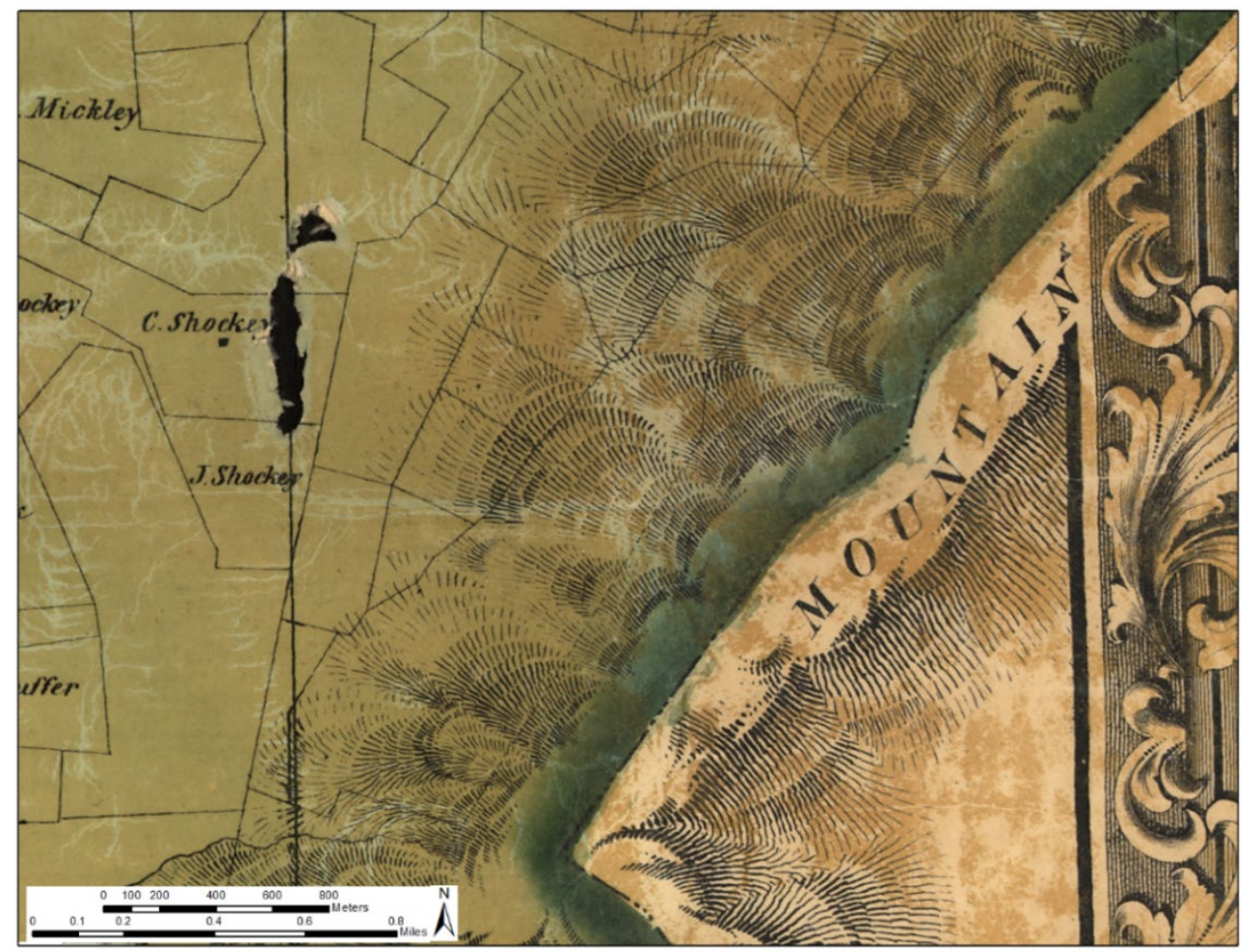

Source: Taggart and Downin (1859). 
Competition was springing up as well. In the 1850 , a hotel called the Monterey Springs Hotel was constructed from an expansion of the earlier Ripple/Burnham Tavern (aka Monterey House) in what is now the Monterey Circle development and golf course. As with the Buena Vista Springs hotel, the original inn was used as an auxiliary building. It was in this structure that Bessie Wallis Warfield (future Duchess of Windsor) was born in 1896 when her parents were guests there (Figure 8) (McClellon ND).

Figure 8. The Monterey House circa 1920.

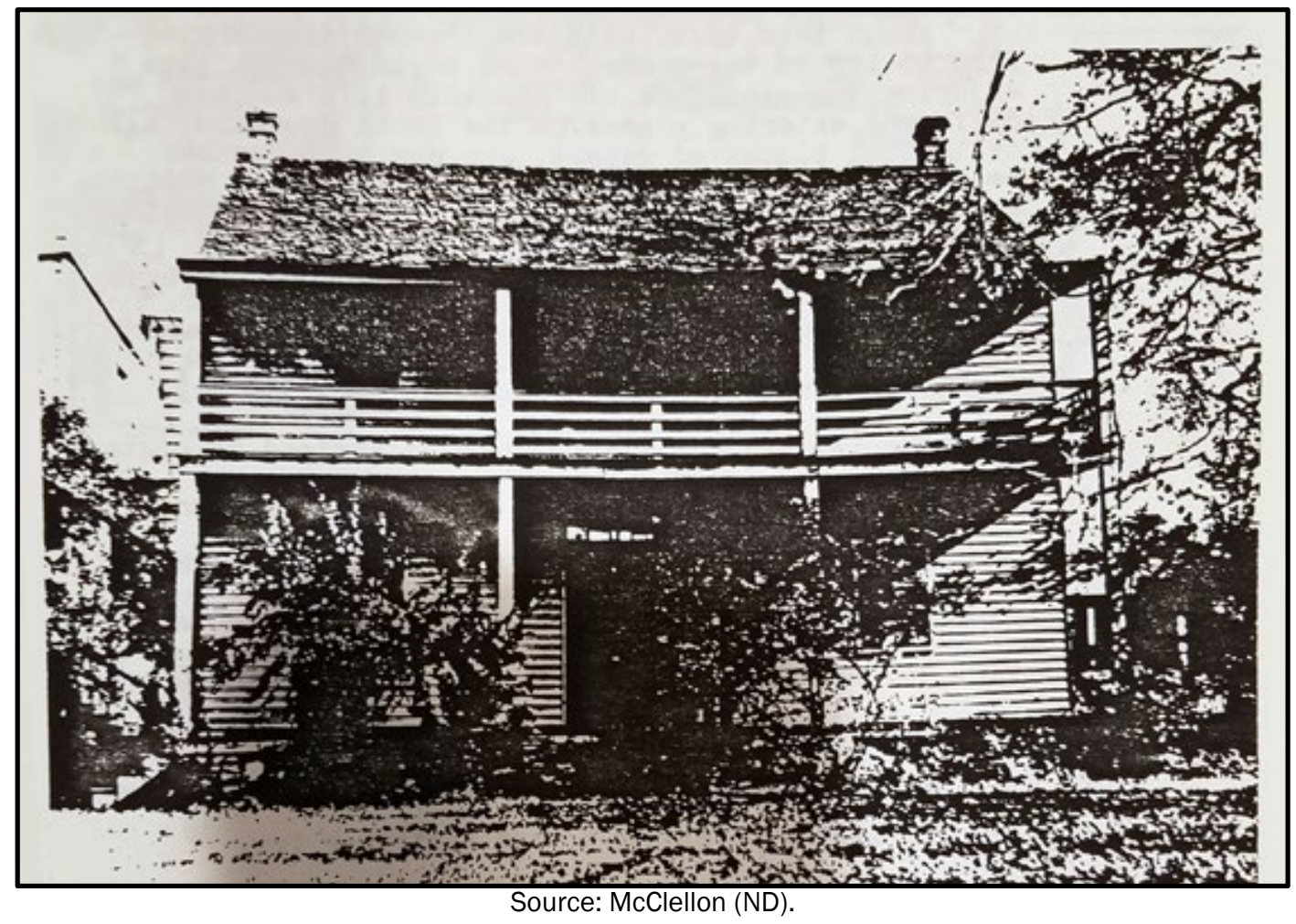

Regional development paused during the Civil War. The Union Army considered Monterey Pass a potential route for a Confederate invasion of the north and Union pickets were regularly posted in the area, patrolling the turnpike between Monterey House and Buena Vista (McClellon ND, Miller 2013). The Confederate Army used Monterey Pass as one of the paths of retreat after the Battle of Gettysburg in 1863. The Confederate wagon trains led the retreat on 4 July 1863 but were but were attacked in Monterey Pass by the Union Calvary under the command of General Judson Kilpatrick in an attempt to block the avenue of retreat (Miller 2013).

Fighting on the slopes of South Mountain lasted throughout the evening and into the early morning of the 5 July 1863 as both sides tried to gain 
control of the high ground that overlooked the Turnpike. Confederate reenforcements arrived on the $5^{\text {th }}$ and General Kilpatrick abandoned Monterey Pass to continue the fight in Maryland. The Confederate Army's retreat through Monterey Pass was completed by the afternoon of the 6 July 1863 . The engagement, known as the Battle of Monterey Pass resulted in 1,300 Confederate casualties as well as the loss of nine miles of wagons from the 50 mile long wagon train; the Union suffered less than 100 casualties (Miller 2013) (Figure 9). Records of the battle indicate that the fighting was concentrated on the northern side of the pass and the slopes of South Mountain. There is no indication in the historical records that fighting occurred on Mount Quirauk on the southern side of the pass.

Figure 9. The Battle of Monterey Pass.

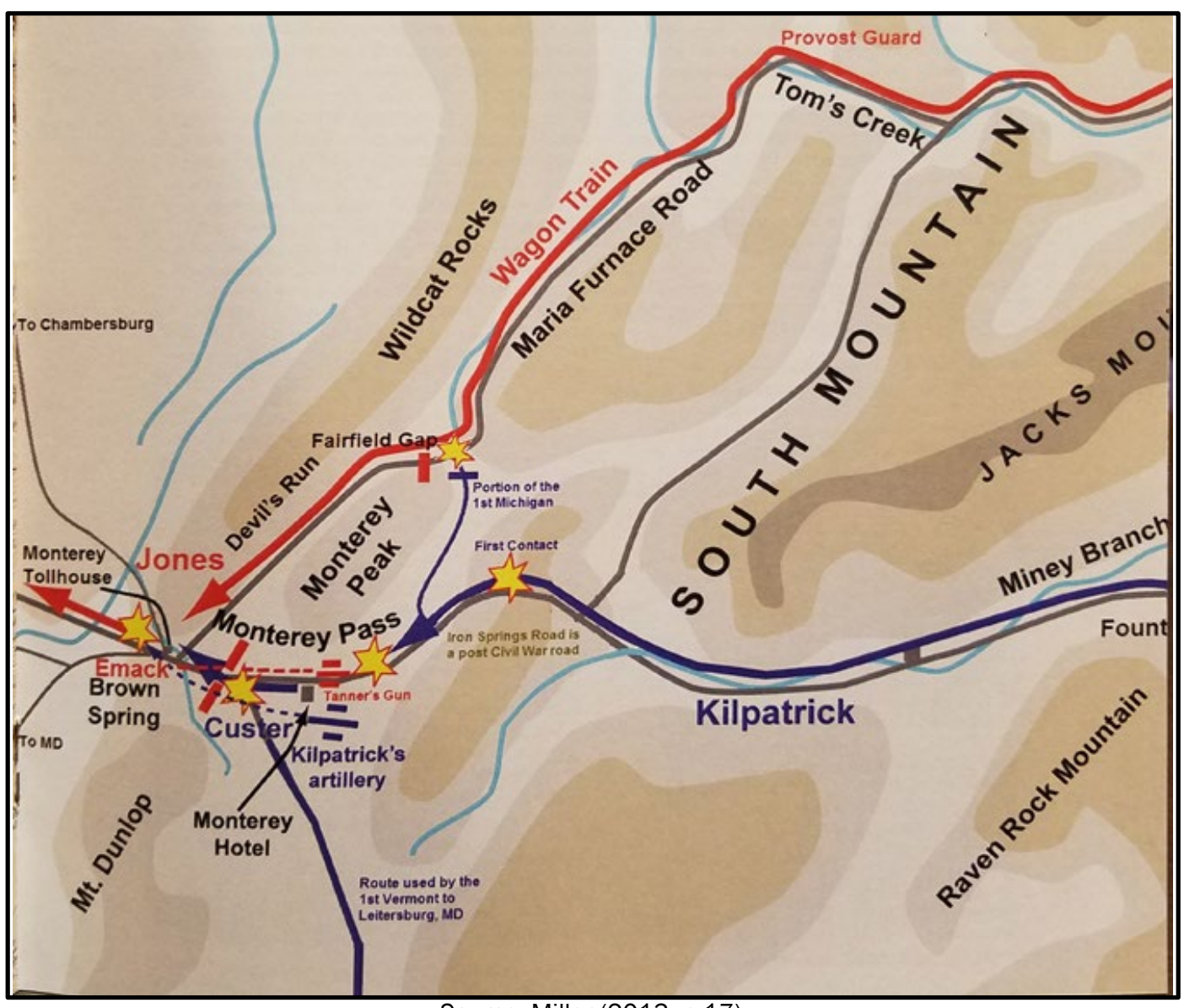

Source: Miller (2013, p 17).

After the war, the development of the area as health resort and watering spot recommenced. Many of the existing hotels changed ownerships and were renovated while new establishments (such as the Clermont House) were opened (McClellon ND). This activity was intensified with the development of Mount Misery on the southern side of the pass. Mount Misery was 
renamed Mount Quirauk to make it more appealing to visitors (Schlotterbeck 1977, Strain 1993). Property on the slopes of Mount Quirauk was purchased by Col. J. Hood, president of the Western Maryland Railroad, in 1871 (Schlotterbeck 1977, Spitzer 1986). The Western Maryland Railroad laid track and established an amusement park called Pen Mar Park as a destination for day trippers from Baltimore, only 70 miles away (Figure 10).

The park opened on 31 August, 1877 and by the turn of the century the park was visited by as many as 20,000 people on the busiest days of the year (Spitzer 1986). Among the many entertainments offered at Pen Mar, some of the most popular were excursions up Mount Quirauk to a scenic overview at High Rock and the summit. A 3-story wooden observatory tower at High Rock was constructed in 1878 and could be reached from Pen Mar by foot or by horse-drawn carriage (Figures 11 through 14) (Ward 1962) along a road constructed by the Western Maryland Railroad. Also along this road were additional scenic overlooks called Brinkwood (Figure 15) and the Ragged Edge (Figure 16). A 70 foot tall wooden observation tower was constructed at the summit of Mount Quirauk in 1883 (Schlotterbeck 1977) and this was replaced by an 80 foot steel tower before 1888 (Phoenixville Bridge Works 1888). This tower was often referred to as Tip Top Tower (Telephone News, 1911) or Mount Quirauk Tower (Schlotterbeck 1977) (Figures 17 and 18).

The growing popularity of automobiles (which allowed travelers a wider choice of destinations), as well as World War I and the Great Depression led to a significant reduction in attendance at the park. The Appalachian Trail was laid down in 1933 and passed by Mount Quirauk with a spur to High Rock but even this could not save the site (Strain 1993). By 1935, the Western Maryland Railroad no longer offered excursion trips from Baltimore to Pen Mar. The park was closed and many of the attractions, including High Rock Tower, were dismantled in 1943 (Spitzer 1986) ${ }^{2}$. By this time, however, Tip Top Tower on the summit of Mount Quirauk, had been repurposed to another function.

In 1921, the Hagerstown, Maryland; Gettysburg, Pennsylvania; and Frederick, Maryland newspapers all reported that the steel tower at the summit of Mount Quirauk was being repurposed as a fire tower jointly staffed by the states of Pennsylvania and Maryland (Forest Fire Lookout Association Undated). This included the laying of phone lines, marking the first time the mountain was used as a communication site. No information was

${ }^{2}$ The current Pen Mar Park was re-opened to the public as a county park on May 22, 1977 (Spitzer 1986). 
found in the historic record regarding the construction of the stone structures (now in partial ruins) that are located near the base of the tower but it is possible that there were buildings constructed to house the men staffing the fire station on Mount Quirauk. Various historic quadrangle maps and aerial photographs depict the roads and structures on Mount Quirauk (Figures 18-23). The 1954 map shows the WJEJ radio tower at the summit; however no records of WJEJ's use of the site could be found other than the cited map.

The modern military presence in the region began in 1926 when the Maryland National Guard established Camp Albert C. Ritchie on the eastern side of Mount Quirauk (Figures 2 and 24) (HAER 1968). The site had previously been used by the Buena Vista Ice Company. During World War II, the U.S. Army operated the Military Intelligence Training Center at the camp (Longe et al. 1998). After the war, the camp was briefly returned to the Maryland National Guard before being permanently acquired by the U.S Army in 1948 to support the Alternate Joint Communications Center/Site R (AJCC) at Raven Rock Mountain, at which time it was renamed Fort Ritchie (Longe et al. 1998). Fort Ritchie entered into a lease for maintenance of portions of the summit of Mount Quirauk in 1951. Construction of military communication facilities on the summit of the mountain began in 1952 (Figure 22). The DoD purchased the site in 1997. 


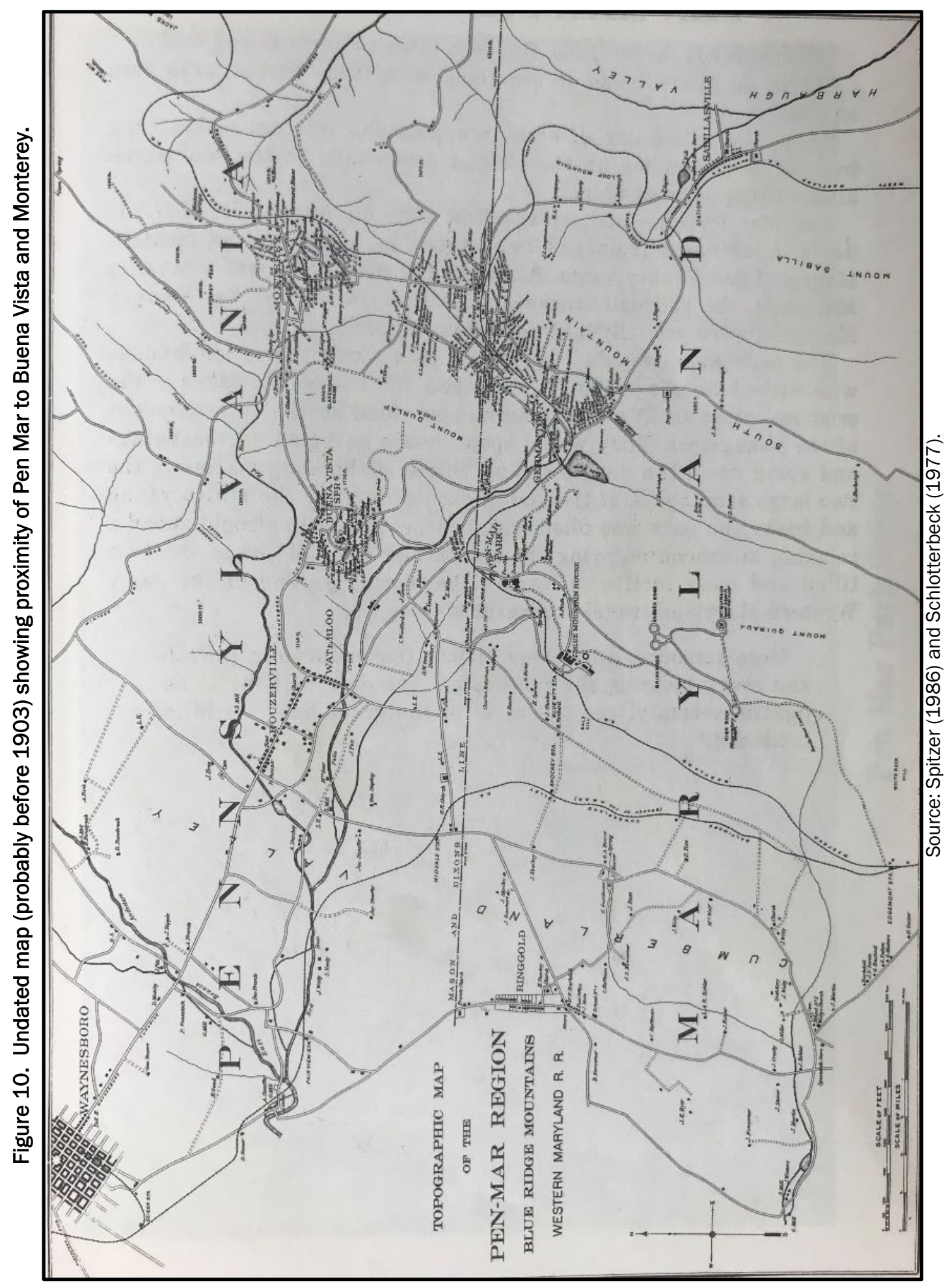


Figure 11. High Rock Observation Tower.

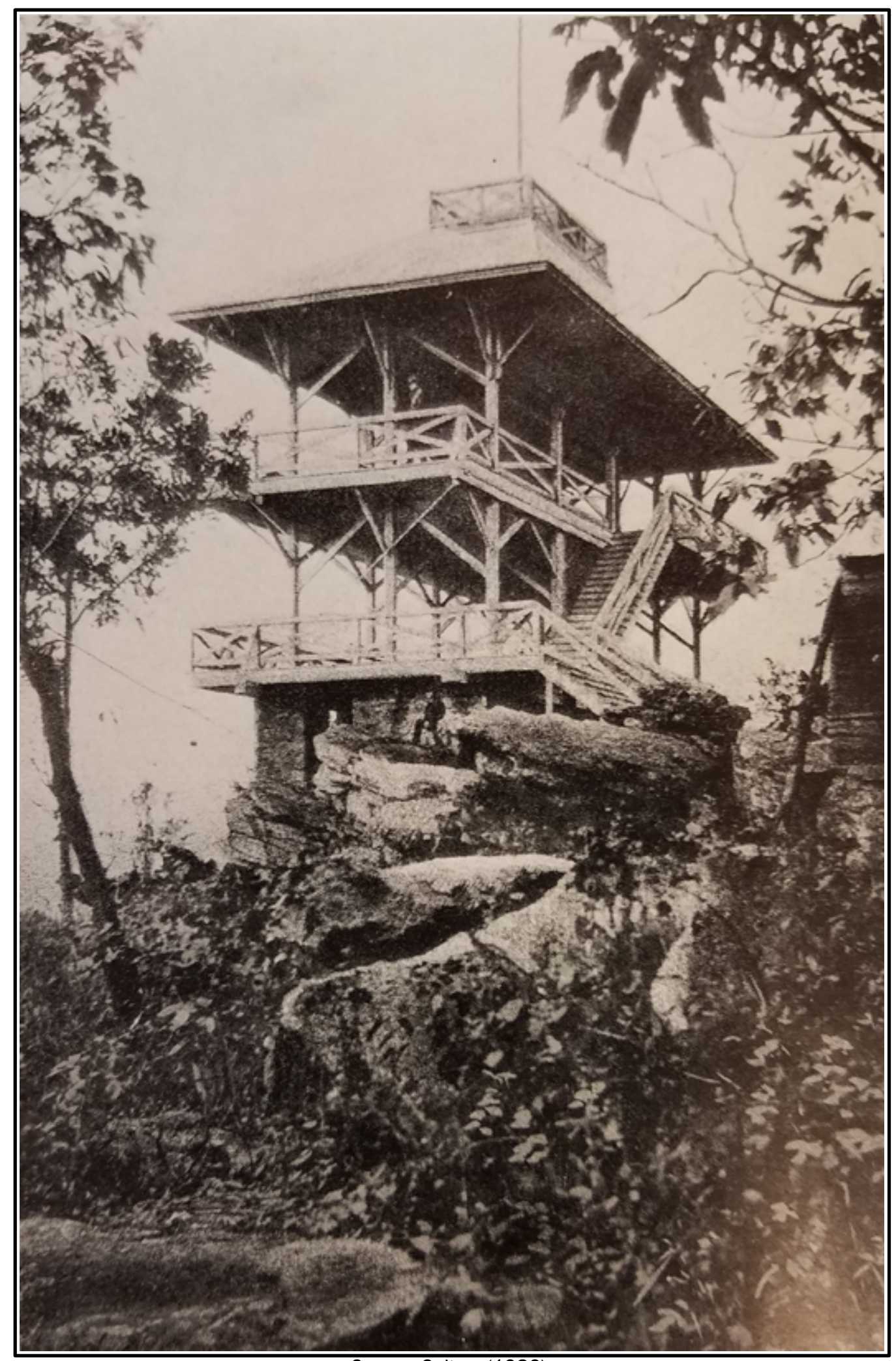

Source: Spitzer (1986). 
Figure 12. Post Card of High Rock.

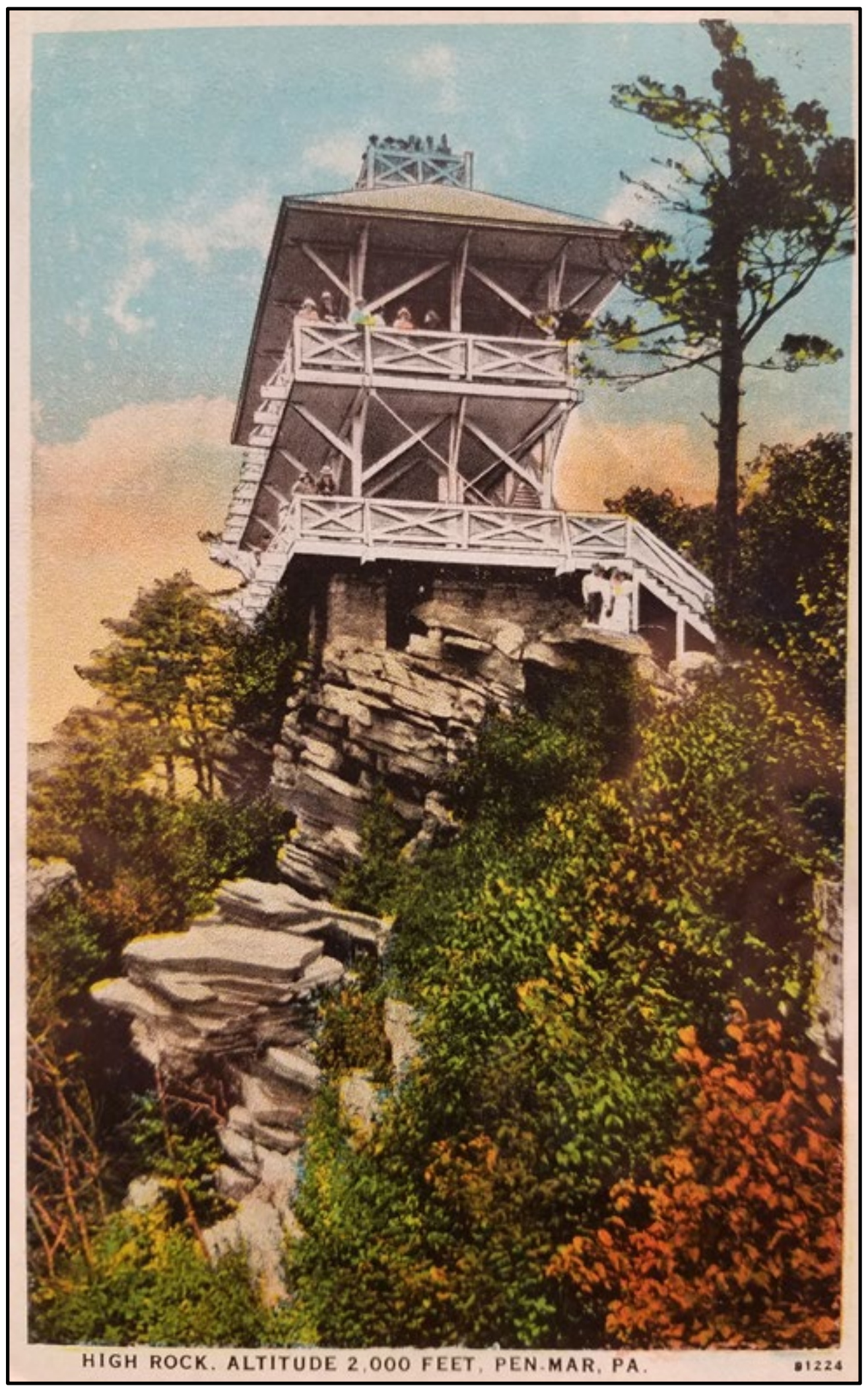

Source: File photo at the Blue Ridge Summit Public Library (ND). 
Figure 13. Period illustrations of Pen Mar and High Rock.

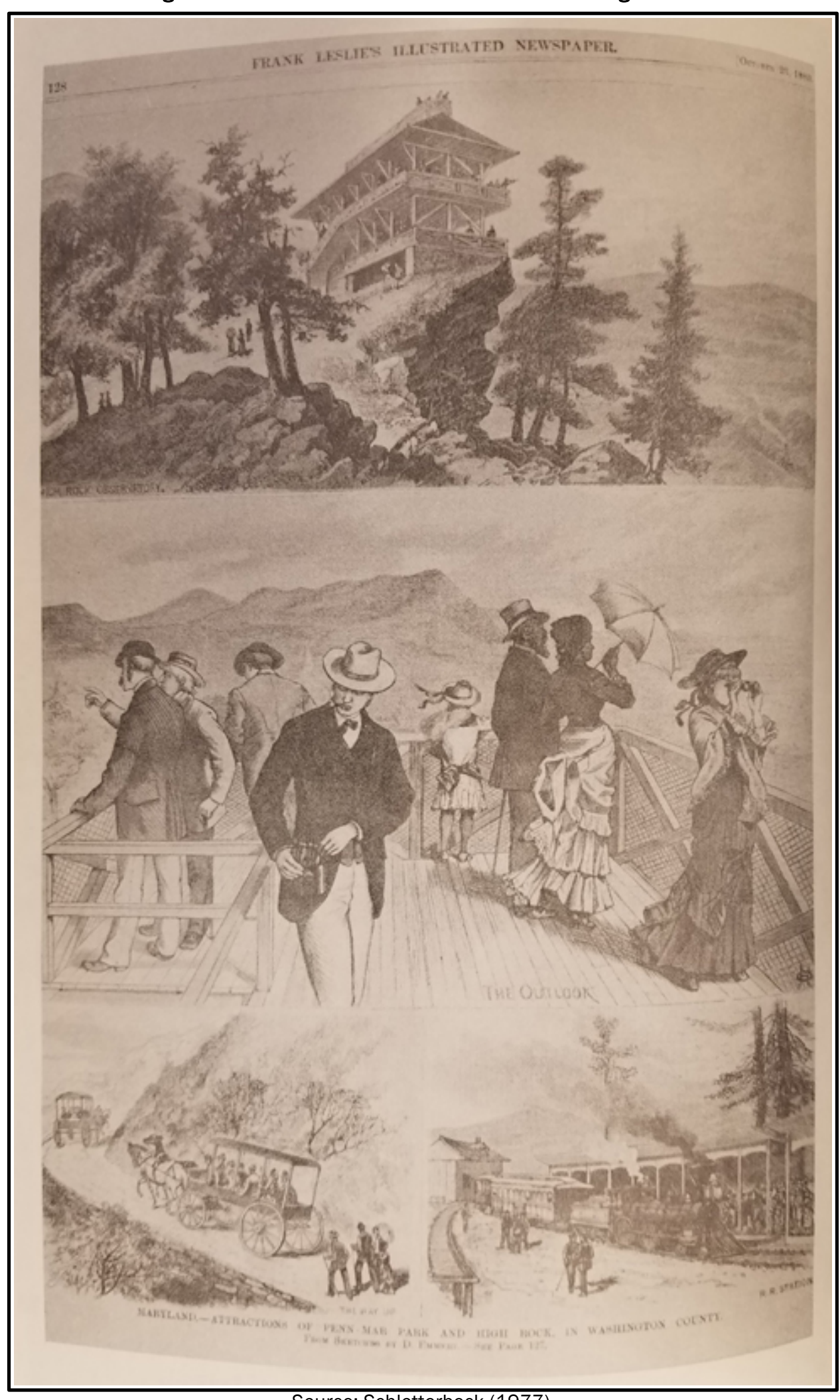

Source: Schlotterbeck (1977). 
Figure 14. High Rock Road.

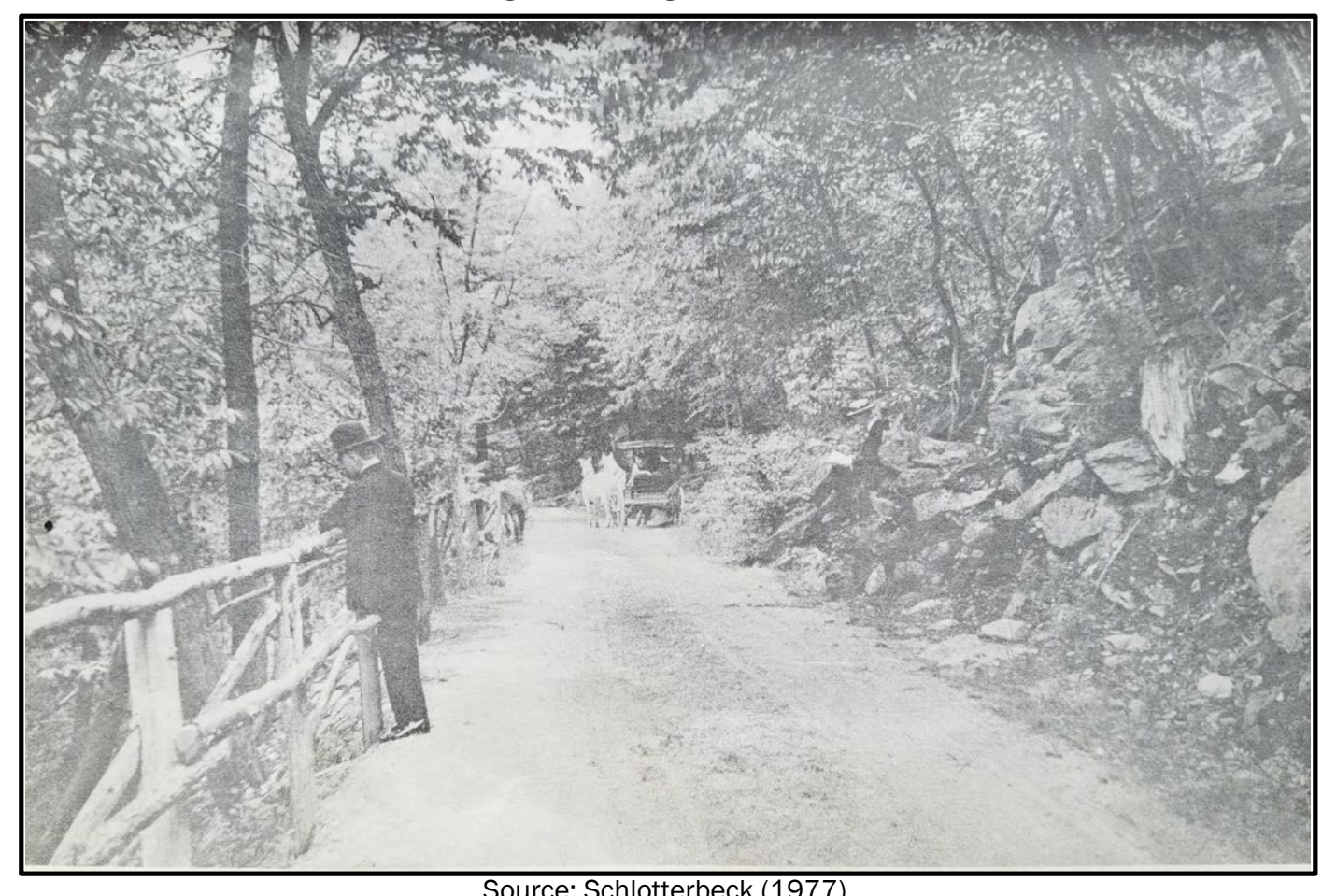

Figure 15. Brinkwood Overlook.

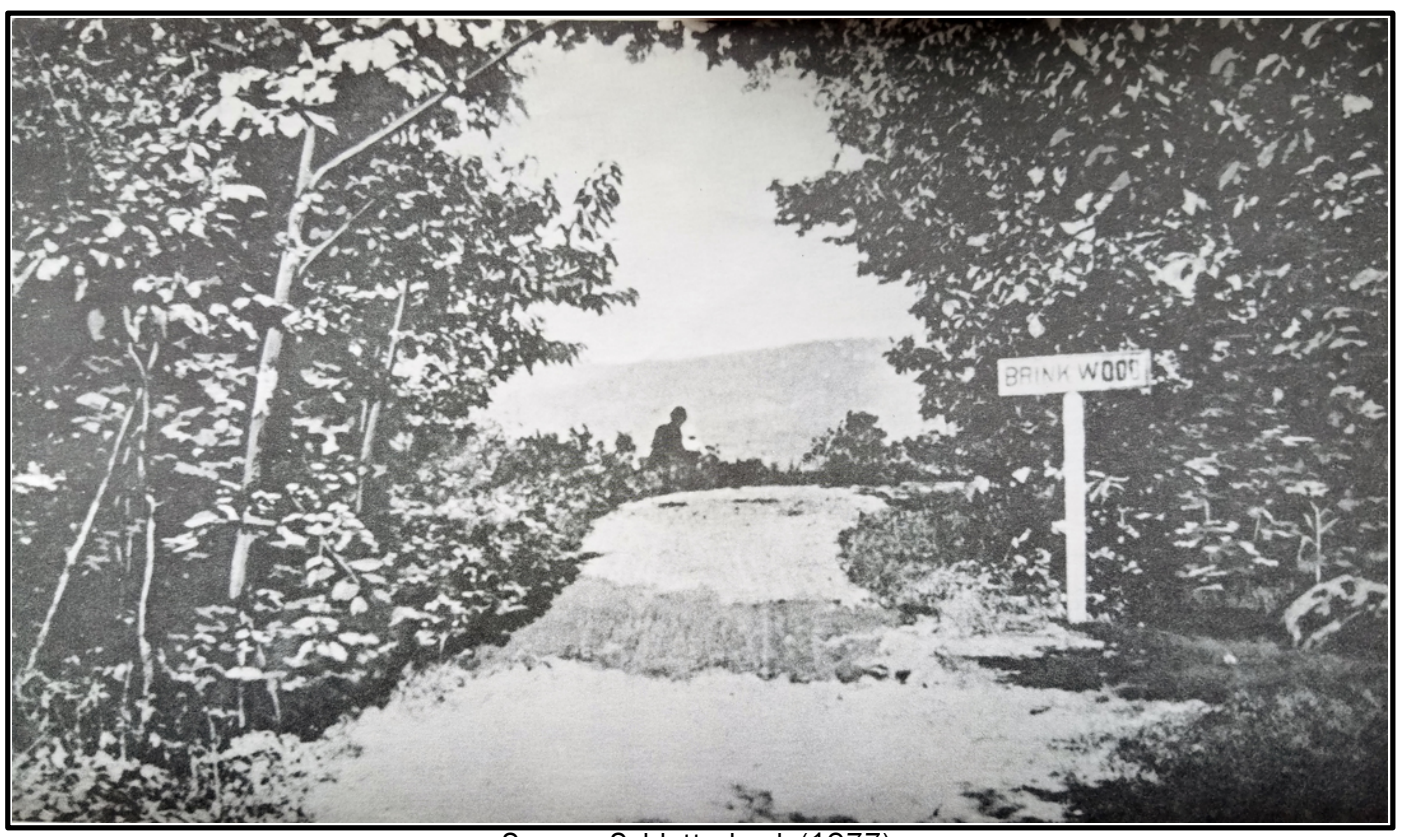

Source: Schlotterbeck (1977). 
Figure 16. Ragged Edge Overlook.

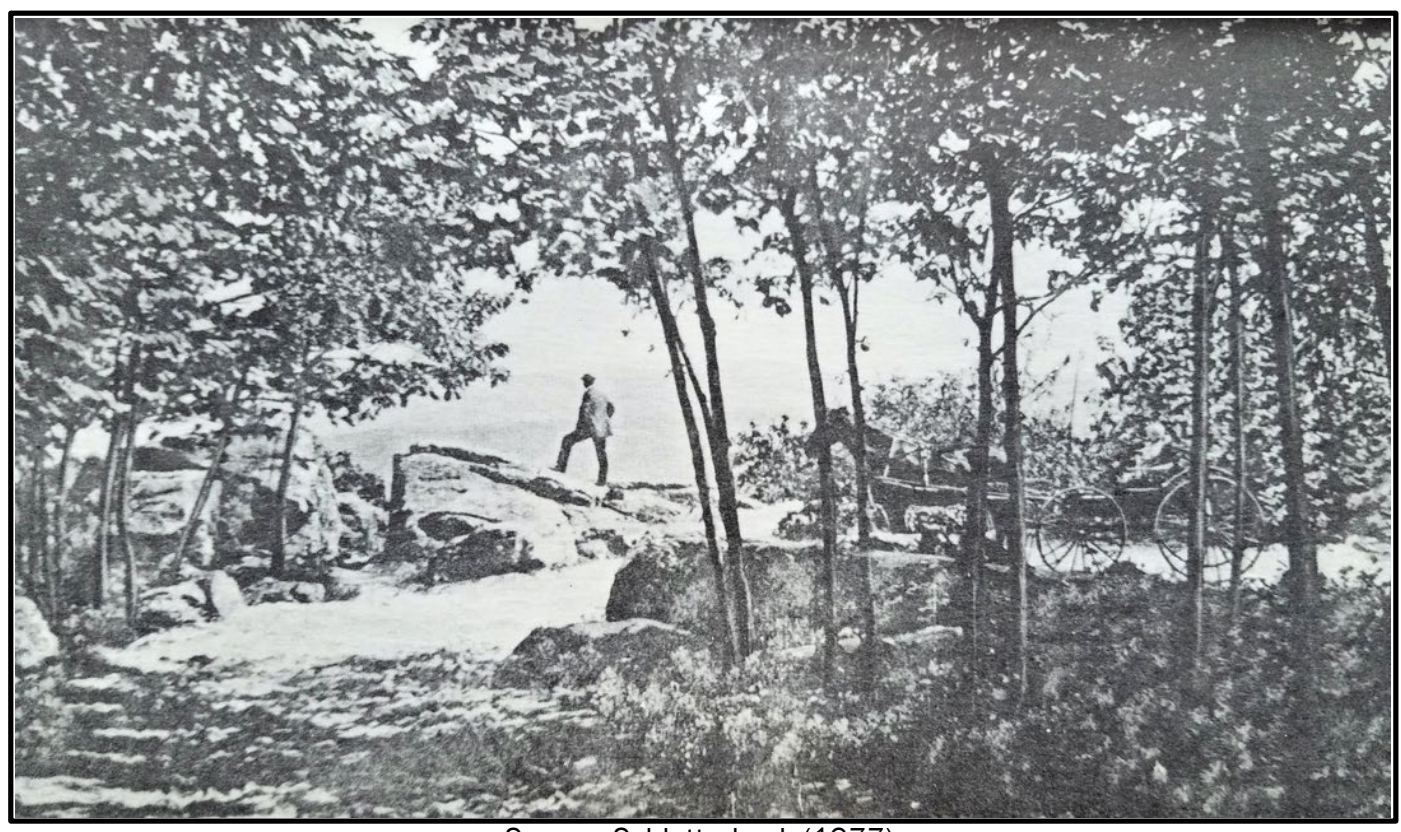

Source: Schlotterbeck (1977).

Figure 17. Post card of Tip Top Tower.

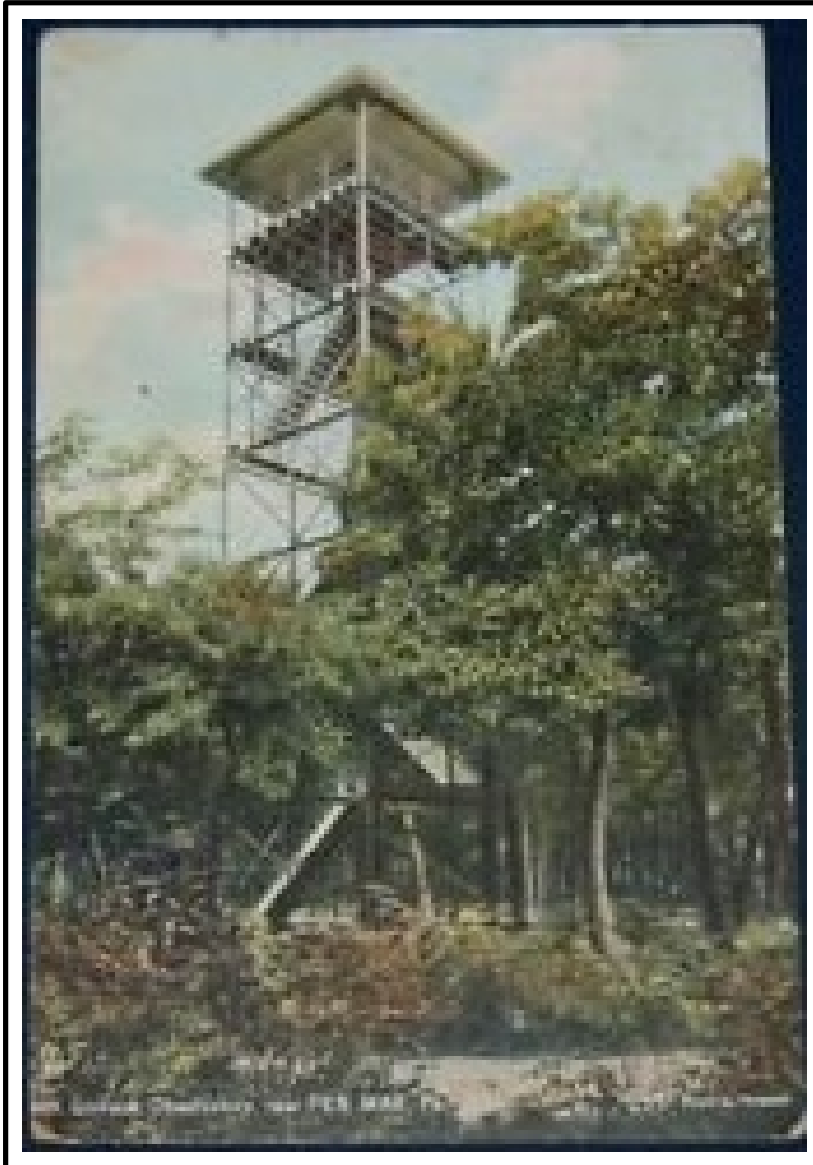

Source: File photo at Blue Ridge Summit Pubic Library (ND). 
Figure 18. Tip Top Tower at the Summit of Mount Quirauk.

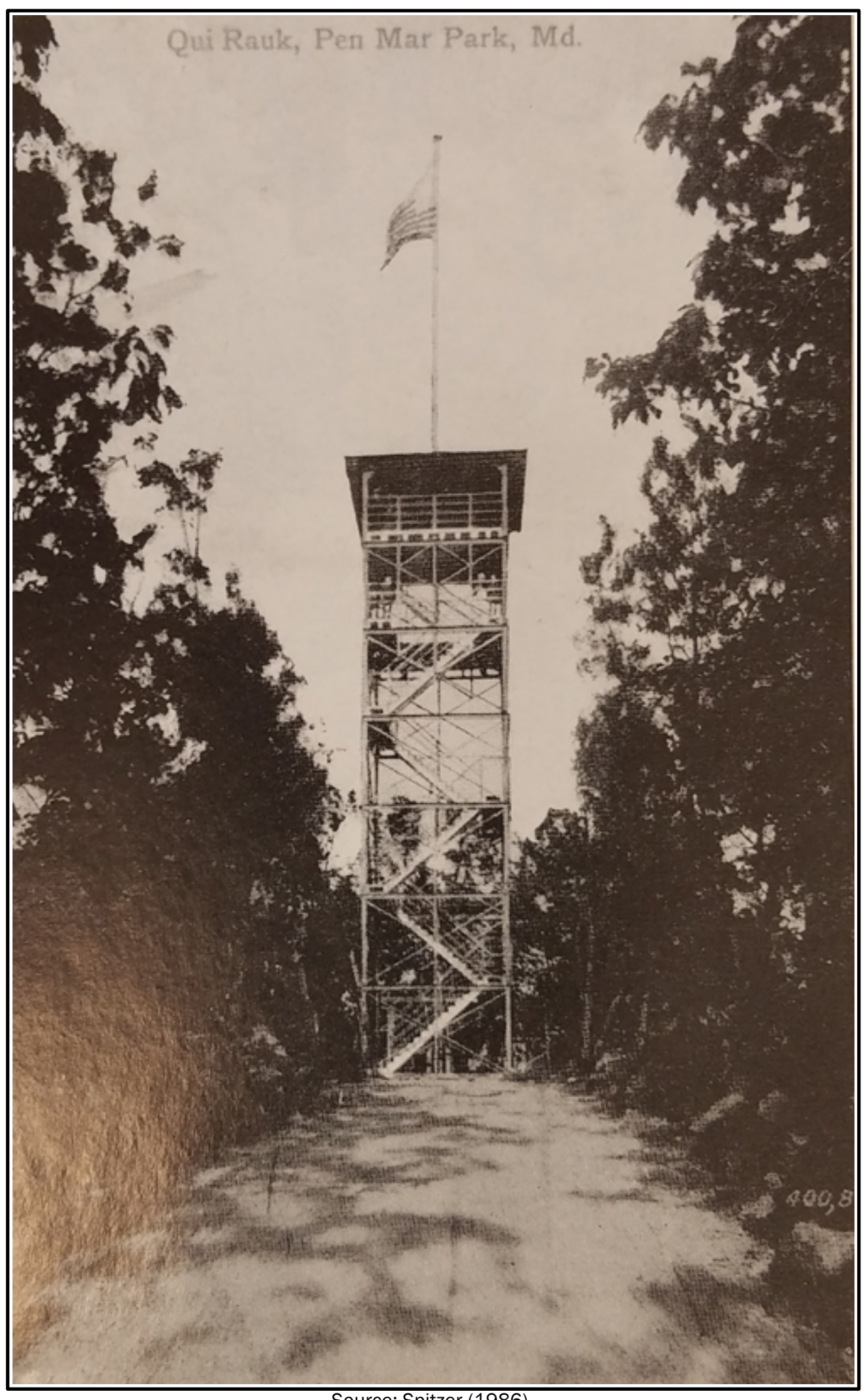

Source: Spitzer (1986). 
Figure 19. 1909 U.S. Geological Survey (USGS) Quadrangle map showing the summit of Mount Quirauk.

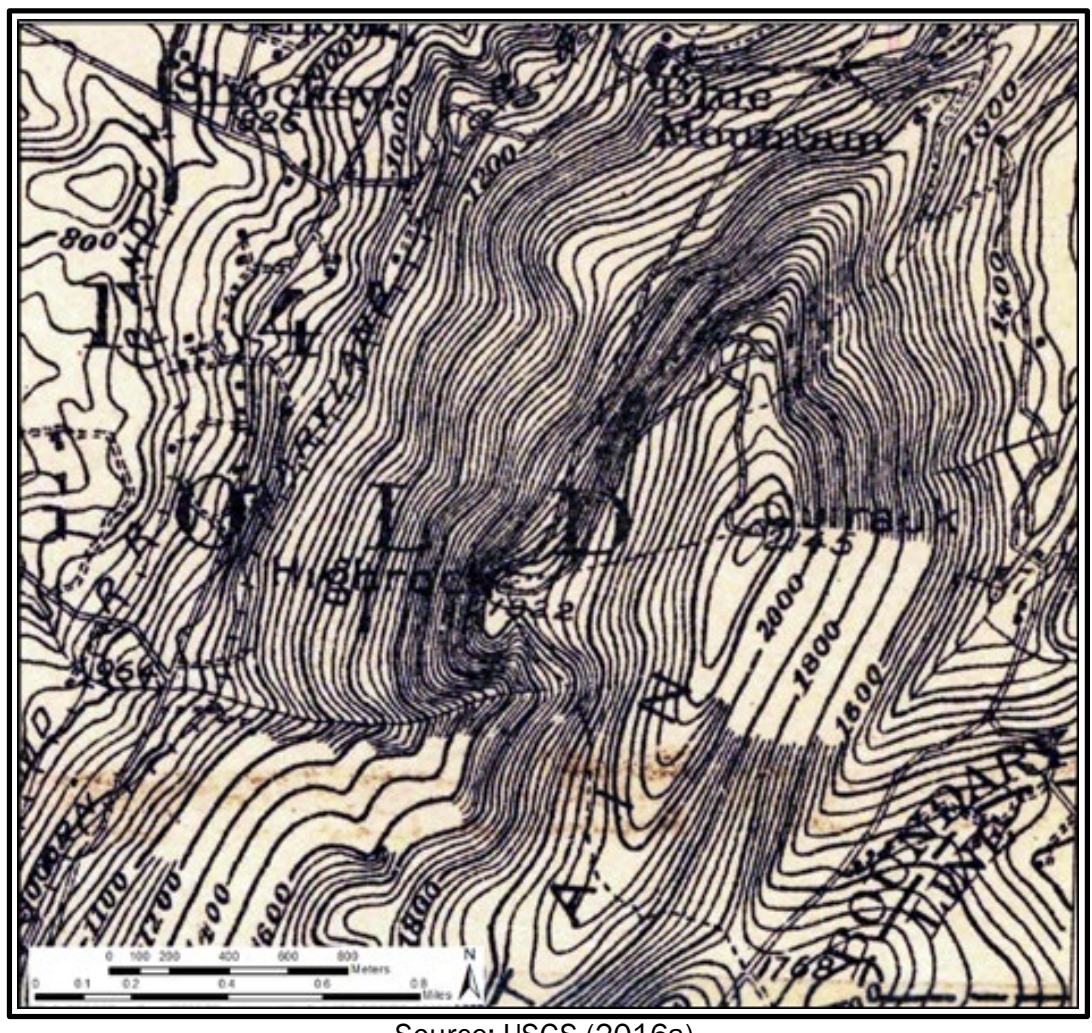

Source: USGS (2016a).

Figure 20. 1938 Aerial photographs of Mount Quirauk.

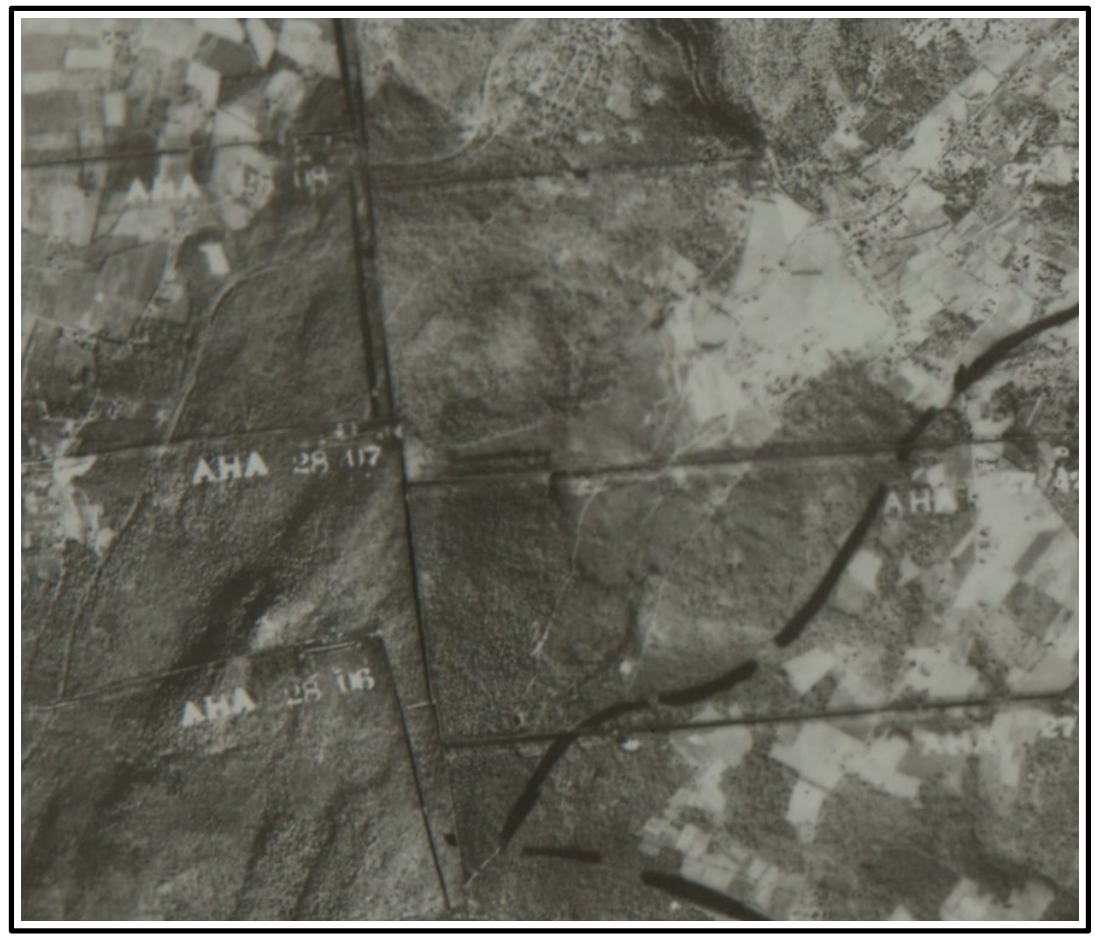

Source: RRMC file photo, attributed to USDA (1938). 
Figure 21. 1942 Smithfield, Maryland Quadrangle Map.

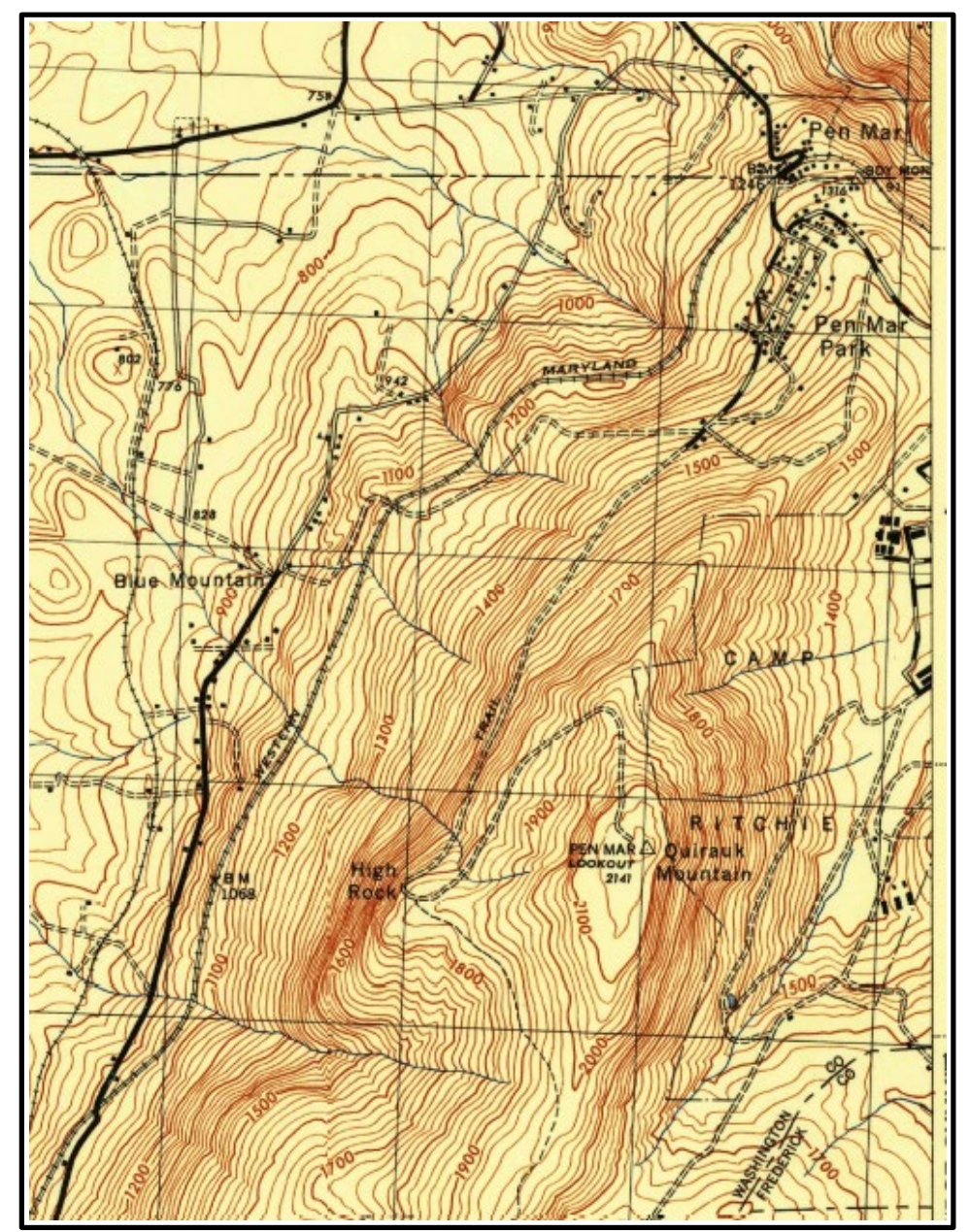

Source: USGS (2016b).

Figure 22. 1952 Aerial of Mount Quirauk and Camp Ritchie.

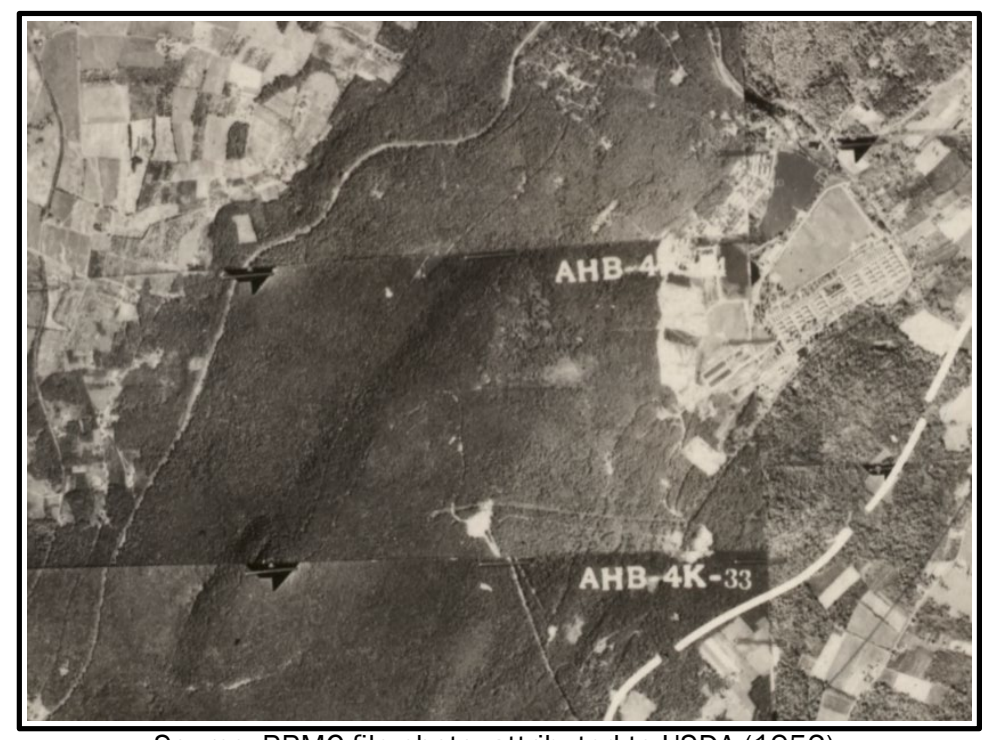

Source: RRMC file photo, attributed to USDA (1952). 
Figure 23. 1953 Smithfield Quadrangle Map of Mount Quirauk.

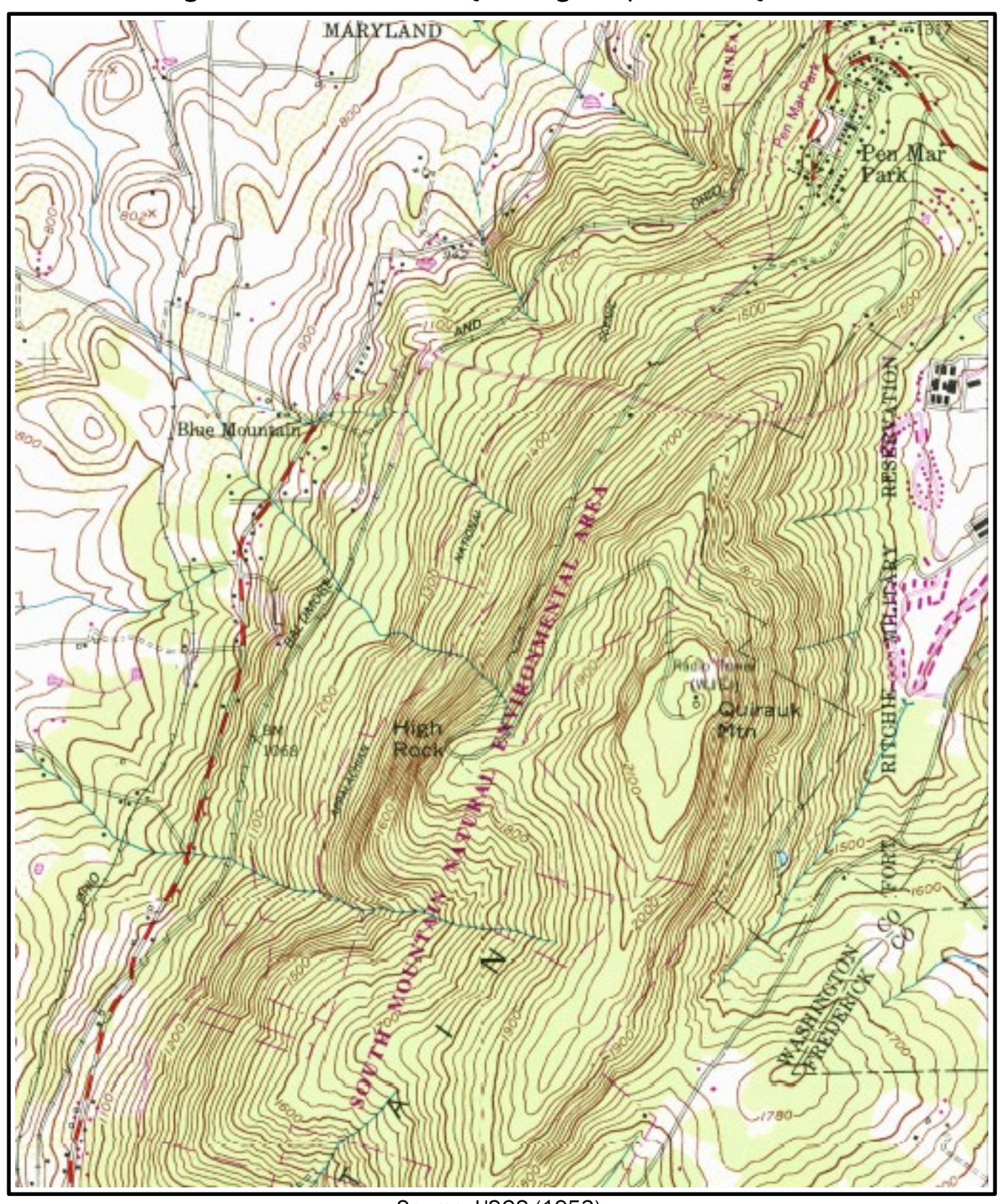

Source: USGS (1953). 
Figure 24. 1983 USGS Quad Map of Mount Quirauk.

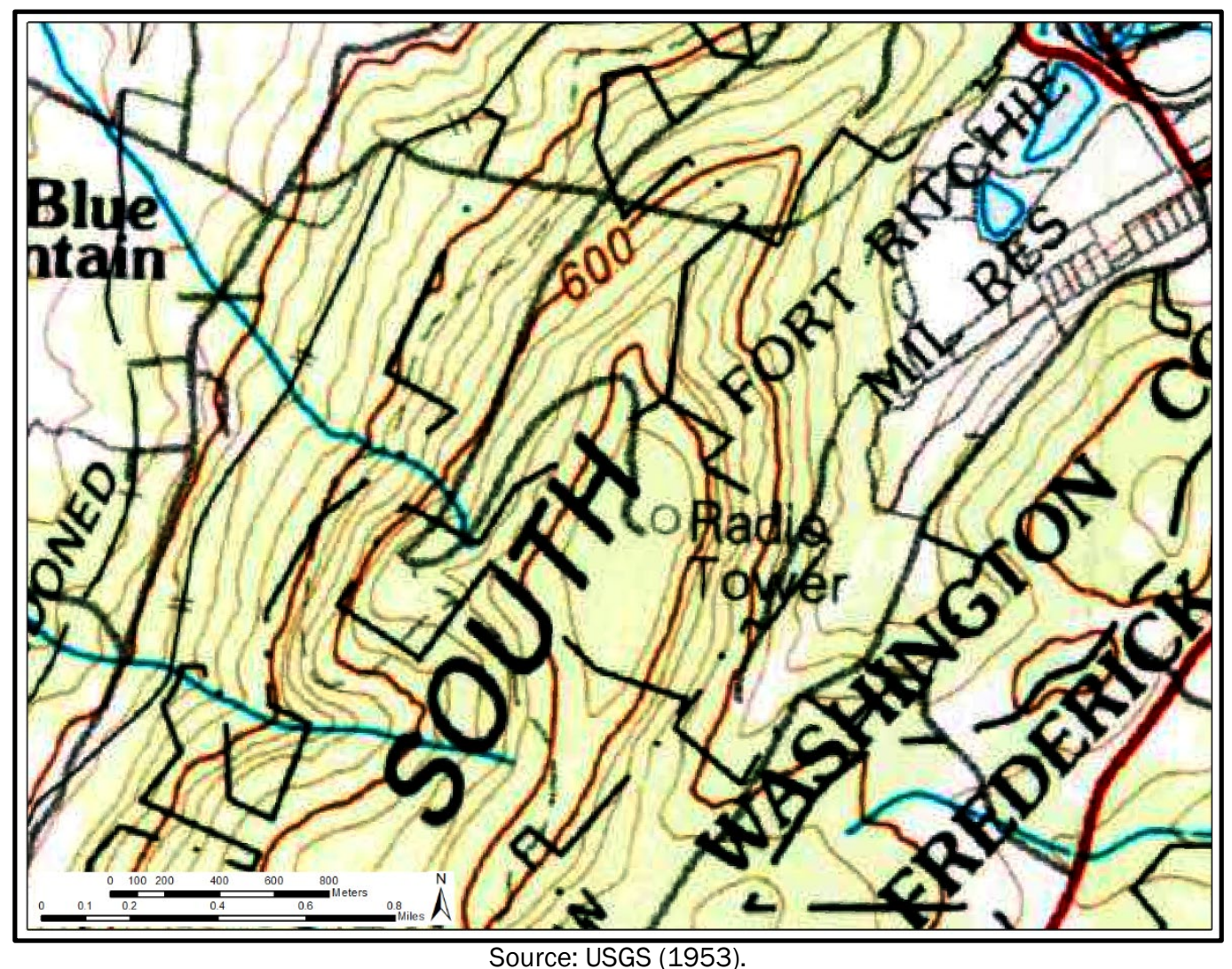




\section{Phase I Survey of Raven Rock Mountain Complex Site C, Maryland.}

The primary archaeological task for ERDC-CERL at Site C was to conduct a Phase I survey to locate and perform a preliminary assessment of any prehistoric or historic sites at the facility. The project area is located at the summit of Mount Quirauk, Maryland, the highest point on South Mountain, at an elevation of 2,145 ft. Fieldwork at Site C was conducted by ERDC-CERL 19-23 March 2018.

\subsection{Methodology}

MHT standards state that, for Phase I surveys, a systematic pedestrian survey may constitute the "primary testing strategy of an area where deep burial processes, such as alluvial, colluvial, or aeolian deposition, are not expected and when the surface of a project area has at least 50 percent exposed soil" (Shaffer and Cole 1994, p 11). Located on top of a mountain, Site $\mathrm{C}$ is not subject to burial processes. The ground surface at the site is heavily littered with natural stone outcrops, boulders, and loose stones resulting from the erosion of the underlying bed rock, occasioning a certainty that the $50 \%$ visibility requirement will be met such that the survey may be conducted as a pedestrian surface survey with occasional soil probes or shovel tests to adequately describe the site's soil stratigraphy. Once the survey was started it was determined that shovel testing would not be productive due to the amount of stone and extremely shallow soils depths. Soil probes were used instead to determine soil depth and composition. The rough terrain and the prevalence of the rock outcrops prevented the researchers from conducting the surface survey in regularly spaced transects. A global positioning system (GPS) track log was used to ensure that the entire project area covered by the survey. The survey area covered the summit and both sides of the road from High Rock to the summit.

Note that security restraints at Site C prevented ERDC-CERL from collecting photographs for this survey. RRMC has collected photographs of the summit and the road to the summit. These photographs are kept on file at RRMC Site R.

Prehistoric site types that are most likely to be considered "significant" under the NRHP guidelines are habitation sites, sacred sites, resource procurement sites and diagnostic isolated finds. Due to the difficult access 
and lack of water sources at the project area, the probability of habitation sites being present is extremely low. The prominent elevation of the site makes it more likely that a sacred site would be present than would habitation sites. Feature and artifact types that would indicate the presence of a sacred site are manmade stone features (such as cairns), areas that appear unnaturally cleared of stone, effigy figurines or figurine fragments, pipes and pipe fragments and/or tools or vessels the size or form of which indicated a ceremonial rather than utilitarian use. All natural rock faces or surfaces of prominent stones should be inspected for the presence of rock art.

The summit of Mount Quirauk consists primarily of exposed stones of Cambrian and Ordovician limestone and dolomite as well as Lower Cambrian quartzite and limestone. Some of these stones are suitable for ground stone tool production, however these stones are common throughout the region and many other sources are much more easily accessible. The evidence for the collection of stone cobbles for ground stone production is extremely ephemeral and tool production usually occurs in habitation sites as opposed to quarry sites. It is unlikely that evidence of this activity would be found at Site C.

Game is another resource that may have been harvested at the site. The site today has clear views of the surrounding valleys and could have been used as a hunting area, however the extreme difficulty in accessing the site might preclude the use of this land as hunting territory. Additionally, the absence of a water source on the mountain top would limit the permanent presence of large game at predictable locations. Expected feature types include isolated finds of projectile points and butchering tools, debitage associated with hunting or butchering tool maintenance, and/or stone features that could be used as hunting blinds. Any isolated finds in the project area would need to be temporally diagnostic to be considered eligible for the NRHP. Of all the prehistoric site types that might be located at Site C, ceremonial/sacred sites and isolated finds are the most likely to be present.

Many of the same geographic and geological factors that limit the likelihood of prehistoric sites also make the presence of historic sites, such as farmsteads, very unlikely. There is a possibility that the site was used for incidental military activity during the Civil War. Confederate routes of retreat after the Battle of Gettysburg passed approximately 5-10 miles north and west of Mount Quirauk and Union troop movements occurred the same distance north, west and east of the mountain. Online research did 
not indicate the existence of historic records of any military activity on the mountain itself. It is possible, however, that military personnel of either side might have climbed the mountain to obtain a better view of the landscape and enemy troop movements but any activity of this nature would be unlikely to be detectable in the archaeological record.

The tourist industry associated with the park at Pen Mar used Mount Quirauk as a scenic excursion. Historic records demonstrated the iron tower at the summit was constructed in the 1880 os and that the road from High Rock was in use late in the $19^{\text {th }}$ and into the $20^{\text {th }}$ century. Because the iron tower and the scenic overlooks of Brinkwood and Ragged Edge are not located on property owned by the federal government, they are not evaluated in this report. A draft nomination to the NRHP for Pen Mar, Maryland was submitted to MHT in July 1999, but it was not formally submitted to the National Park Service (Taylor 1999). The boundaries do not include the road leading up to High Rock or the Mount Quirauk tower. At this time the Pen Mar High Rock Road, the road to Mount Quirauk (including Brinkwood and Ragged Edge overlooks, and the Mount Quirauk tower should be considered potentially eligible for the NRHP under Criterion A until a formal determination is made.

\subsection{Phase I Results}

The Phase I survey area was 30 hectares ( 76 acres) in size. It covered the summit area, both sides of the road to the summit and the flatter area east of the High Rock observatory area (Figures 25 and 26). At the time of the survey, some areas to the east and west of the road just before the summit had already been impacted by the construction of parking areas. A letter shown to the field crew by the staff of RRMC environmental office documented that this area had been visually inspected by persons from the MHT before the undertaking.

No evidence was discovered to indicate any prehistoric features at Site C or along the road approaching it. No prehistoric artifacts were recovered. Considering the difficulty in accessing the site and the distance to water sources, it is extremely unlikely that any prehistoric occupation would have occurred at this site. The prominence of the mountain did not preclude, however, the sites use as a ceremonial or spiritual area. Special attention was paid to all stone outcrops to search for any signs of rock art or cairns but none were identified. 
No historic artifacts were encountered on the federally owned property other than modern debris such as plastic soda and water bottles. The lack of historic trash from the Pen Mar tourist era is not too surprising. There is no record of any facilities on the summit other than the tower. People making the accent would expect to reach the summit, look around and then descend. If any provisions, such as water, were taken to the summit, it would have been in reusable vessels such as canteens that would not be discarded at the summit.

There was some construction debris including wooden fencing pieces, wire and spray paint bottles in the vicinity of the radio building south of the Site $C$ fence line (-77.512814 39.694309) but the survey crew was advised by the RRMC escort that this area was not owned by the federal government and was not part of the survey.

The original iron tower that is visible in the early photographs of the site is still standing at the summit as is a stone building to the north of the tower. The stone building is most likely associated with the use of the site as a fire station, starting in the 1920 s. Such a site would have needed to be continuously staffed and living quarters would be needed for the staff. Historic domestic debris was seen on the surface behind the building (north side of the structure) that included intact glass bottles, cans and glass medicine bottles. This material was not collected as the land was not owned by the government and fell outside of the scope of this survey.

A trash dump area was observed on the west side of the road about half way between Site $\mathrm{C}$ and the turnoff to Brinkwood and Ragged Edge observation points (-77.514221 39.699644). This site was adjacent to two borrow pit features that at the time of survey were filled with water. The trash debris seen at the surface in this dump area was fairly large and included a crib-sized mattress, multiple tires, metal barrels, and barrel fragments. Dateable material appeared to be from the early to mid- $20^{\text {th }}$ century. Again, because this area was outside of the property owned by RRMC no artifacts were collected from this location since management of this site falls outside of the jurisdiction of RRMC.

The historic overlooks of Brinkwood and Ragged Edge are still accessible from the Mount Quirauk access road. The roads to these overlooks have not been maintained but the road trace is still clearly visible and easily followed. Near both observation points there are low stone walls along the 
road boundary. Some historic debris, such as a glass bottle fragments, was observed at Ragged Edge. No artifacts were observed at Brinkwood. These sites are outside of the RRMC property line and are not part of the scope of this report. No artifacts were collected from these sites.

Along the path of the road there were several widened areas that extended into the trees. These features bore the distinct characteristics of bulldozer push piles and are most probably associated with the construction and maintenance of the road. No historic artifacts were found within these areas.

The flat area east of the High Rock observation area was examined for traces of the direct path from High Rock to the summit (Figure 26). The dashed line on this map indicates that it is a foot path and not a road like the roads to the summit, Brinkwood, and Ragged Edge. No trace of the path was found.

Figure 25. Area covered by Phase I survey (ERDC-CERL, 2018)

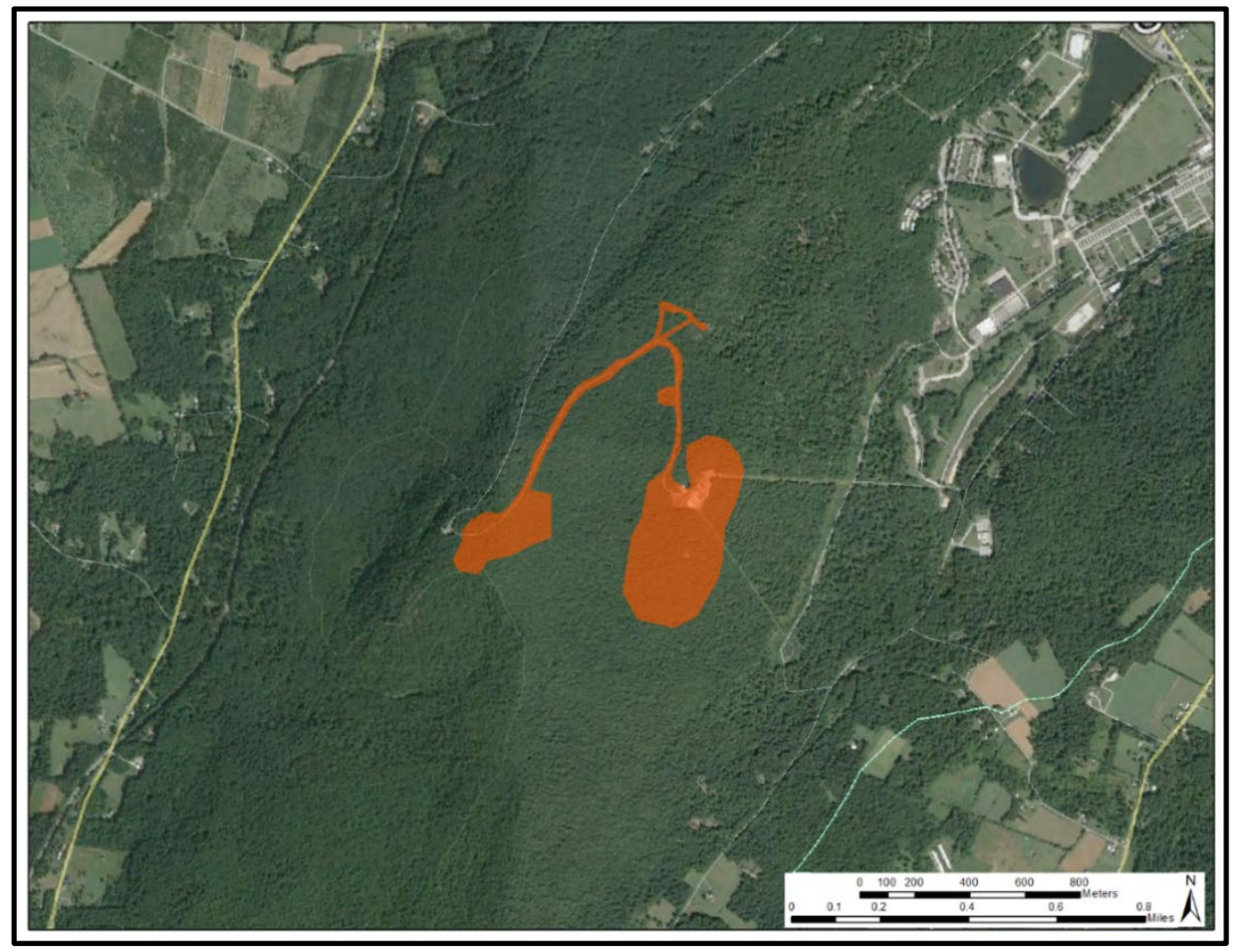


Figure 26. Survey area on Western RR Map.

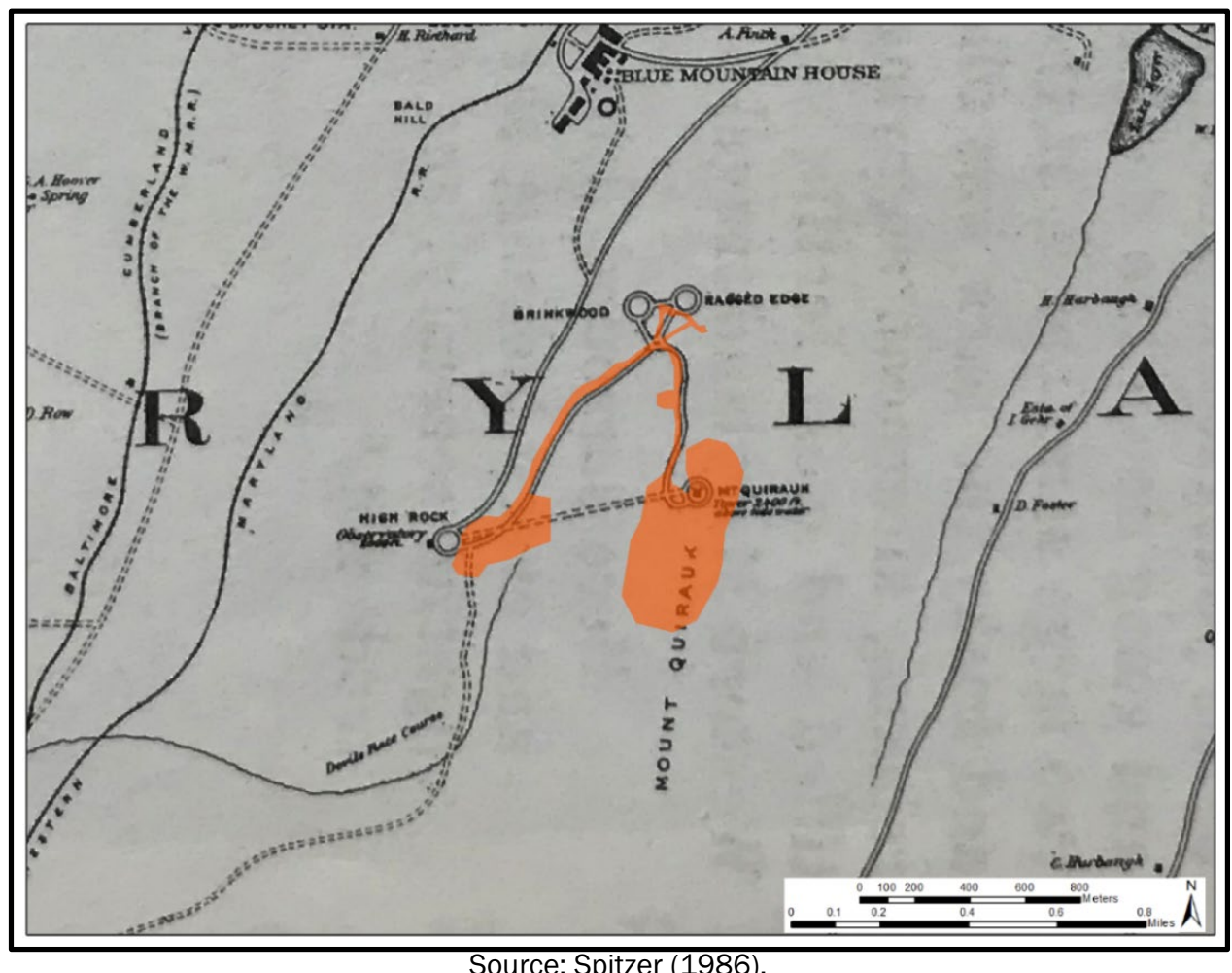

A series of soil probes were collected throughout the project area. The first three probes were in association with an apparent bulldozer push pile and depression.

- Soil Probe 1 inside bulldozer push pile depression - Universal Transverse Mercator (UTM) 2884404E, 4397081N, o-16cmbs humus, 16$23 \mathrm{cmbs} 10 \mathrm{YR} 4 / 4$ sandy loam, $23 \mathrm{cmbs}$ rock.

- Soil Probe 2 outside bulldozer push pile - UTM 284400E, 4397086N, 0-18 cmbs humus, $18-20$ cmbs 5 YR 4/2 sandy loam, 20-28 cmbs $2.5 \mathrm{Y} 6 / 6$ sand, 28 cmbs rock.

- Soil Probe 3 outside bulldozer push pile - UTM 284405E, 4397079N, o-10 cm humus, $10-15$ cmbs 5 YR 2.5/1 sandy loam, $15-18 \mathrm{cmbs}$ $2.5 \mathrm{YR} 5 / 6$ sandy loam, $18-31 \mathrm{cmbs} 10.5 \mathrm{Y} 4 / 1$ with large inclusions of $7.5 \mathrm{YR} 5 / 6$ sandy loam, 31 cmbs rock.

- Soil Probe 4- UTM 28440oE, 4396997N, 0-9 cmbs humus, 9-16 cmbs 2.5YR3/1 sandy loam, 16-18 cmbs 10YR5/6 sandy loam, 18 cmbs rock.

- Soil Probe 5 - UTM 284531E, 4396887 N, 0-3.5 cmbs humus, 3.5 cmbs rock. No established soil

- Soil 6 - UTM 284514E, 4396824N - 0-4 cmbs humus, 4-7 cmbs 5YR 2.5/1 loam, 7 cmbs rock. 


\section{Determination of Eligibility for the NRHP}

NRHP eligibility is determined if a property possesses historic significance and sufficient integrity to represent that significance.

\subsection{Significance}

Significance is defined as the meaning or value ascribed to a cultural landscape based on the NRHP criteria for evaluation. There are four eligibility criteria against which site significance is evaluated for the NRHP. These four criteria, fully described in National Park Service Bulletin No. 15, How to Apply the National Register Criteria for Evaluation (NPS 1991, p 11), are

- Criterion A applies to properties associated with events that have made significant contributions to the broad patterns of history.

- Criterion B applies to properties associated with the lives of persons significant in our past.

- Criterion $\mathrm{C}$ applies to properties embodying the distinctive characteristics of a type, period, or method of construction; possessing high artistic values; or representing a significant and distinguishable entity, the components of which may lack individual distinction.

- Criterion D applies to properties that have yielded or are likely to yield, information important to prehistory or history.

\subsection{Integrity}

Integrity is defined as the authenticity of a property's identity, evinced by the survival of the site's physical characteristics. Archaeological integrity describes the quality of information and level of preservation for an archaeological site, district, or assemblage. Good archaeological integrity is ascribed to properties that are relatively intact and complete, and that have not been significantly impacted by later activities or natural processes. Poor integrity indicates that the site has been disturbed through the actions of people (such as ground disturbances or artifact collecting) or by natural processes such as erosion. The archaeological record, however, is complex; any determination of integrity must be made within the historical and modern context of the property. 
Archaeological integrity is evaluated on seven aspects, which are fully described in Bulletin No. 15 (NPS 1991, p 44-49), and which may be summarized as

- Location: the place where the item was constructed/manufactured or a historic event occurred;

- Design: the elements that constitute the form, plan, space, structure and style of a property;

- Setting: the physical environment of a property;

- Materials: the physical elements or parts that were combined or deposited in a pattern or manner to form an archaeological property;

- Workmanship: the evidence of the labor and skill of a culture or people;

- Feeling: the expression of the aesthetic or historic sense of a particular period of the past; and

- Association: the direct link between an important historic event or person and a historic property. (Under Criterion D, the link is measured in the strength of association between data and important research questions.)

Archaeological properties rarely have undisturbed cultural deposits. Longterm occupation or repeated revisiting of sites creates complex stratigraphy. Features visible above ground and the distribution of artifacts may be used as evidence of below-ground integrity. For properties considered eligible under Criterion D, integrity relates directly to the ability of the site to provide information to the research questions defined within the archaeologist's or installation's research design. In general, however, archaeological integrity is demonstrated by the presence of spatial patterning of artifacts or features that represent differential uses or activities and the lack of serious disturbance to the property's archeological deposits (NPS 1991, pp 46-49).

\subsection{Findings at Raven Rock Mountain Complex Site C}

This Phase I survey does not indicate the presence of archaeological sites within the property boundaries of Site $\mathrm{C}$ that require any mitigation.

Investigations of historic maps indicated that the current road to Site $\mathrm{C}$ from High Rock follows the same path as the historic road. Photographic evidence also shows that the old metal tower at the summit of Mount Quirauk is the same as the one in historic photographs; it dates to at least the turn of the $20^{\text {th }}$ century and may date back to the 1880 s. Several features 
from the historic use of Mount Quirauk are still present. This includes the iron tower at the summit, stone structures near the base of the structures that are most likely the habitation for the forestry rangers that occupied the site, the constructed observation points of Brinkwood and Ragged Edge, and the road. All of these features are potentially eligible or eligible for inclusion on the NRHP but only the road from High Rock to Site C is owned and managed by RRMC. As a result their eligibility status does not fall under the jurisdiction of RRMC. Nevertheless, activities at RRMC may impact these sites indirectly - particularly the viewsheds of these sites. Brinkwood and Ragged Edge face away from Site $\mathrm{C}$ and no activity at Site $\mathrm{C}$ would impact the viewshed at these sites. The iron observation tower at the summit of the mountain is immediately adjacent to Site $\mathrm{C}$ and construction at Site $\mathrm{C}$ may impact the viewshed from this historic property. Changes to the right-of-way for the road from High Rock to Site $\mathrm{C}$ will have to be consulted with the MHT.

No artifacts, with the exception of modern debris such as plastic soda bottles were identified in the survey at Site C. Some historic debris, including historic domestic debris and intact medicine bottles were seen on the surface immediately north of the historic stone structures but as these were not on federal property they were not collected for additional examination. A trash dump area was observed on the west side of the road about half way between Site C and the turnoff to Brinkwood and Ragged Edge observation points. This site was adjacent to two ponds that may be seasonal in nature and located in possible borrow pit features. The trash debris seen at the surface in this dump area was fairly large and included a crib-sized mattress, multiple tires and metal barrels, and barrel fragments. Dateable material appeared to be from the mid-20 $0^{\text {th }}$ century. Again, because this area was outside of the property owned by RRMC, no artifacts were collected from this location and management of this site falls outside of the jurisdiction of RRMC. Along the path of the road there were several widened areas that extended into the trees. These features bore the distinct characteristics of bulldozer push piles and are most probably associated with the construction and maintenance of the road. No historic artifacts were found within these areas.

No evidence was discovered to indicate any prehistoric features at Site C or along the road approaching it. Considering the difficulty in accessing the site and the distance to water sources it is extremely unlikely that any prehistoric occupation would have occurred at this site. The prominence of 
the mountain did not preclude, however, the sites use as a ceremonial or spiritual area. Special attention was paid to all stone outcrops to search for any signs of rock art or cairns but none were identified. 


\section{Final Recommendations for Eligibility and Conclusion}

This Phase I survey does not indicate the presence of archaeological sites within the property boundaries of Site $\mathrm{C}$ that require any mitigation. There are, however, potentially eligible resources outside of the RRMC property boundaries. These include the iron tower and stone structures at the summit of Mount Quirauk, the two observation points along the road to the summit (Brinkwood and Ragged Edge), and potentially the trash dump also along the road to the summit. Activity at Site $\mathrm{C}$ may affect the integrity of these features, particularly the iron tower, and stone structure at the summit of the mountain. Interference with line of sight from these historic properties, particularly the iron tower should be documented before any construction within the military lands. The road from High Rock to Site C is owned by RRMC and also is potentially eligible for the NRHP under Criterion A; changes to it will need to be consulted with the MHT. 


\section{Bibliography}

\section{Cited works}

Andrews, Matthew P. 1929. A History of Maryland: Province and State. Garden City, NY: Doubleday, Doran and Company, Inc.

Baltimore District (U.S. Army Corps of Engineers, Baltimore District) 2001. Phase I Cultural Resource Investigation: Alternative Joint Communication Center Site $R$, Raven Rock Mountain. Report submitted to the U.S. Army Garrison Fort Detrick, Director of Installation Service, Environmental Management Office.

Davison, D. H. 1858. Map of Franklin County, Pennsylvania from Actual Survey. Greencastle, PA: Riley and Hoffman.

Fry, Joshua, and Peter Jefferson. 1753. A Map of the Inhabited Part of Virginia Containing the Whole Province of Maryland with Part of Pennsylvania [sic], New Jersey and North Carolina. London: Thomas Jefferys Geographers. https://www.loc.gov/resource/g3880.ct000370/?r=0.031,-0.339,0.926,1.252,0

Grimmer, Anne E. 2017. The Secretary of the Interior's Standards for the Treatment of Historic Properties with Guidelines for Preserving, Rehabilitating, Restoring \& Reconstructing Historic Buildings (revision of a 1995 document of same name by Kay D. Weeks and Anne E. Grimmer). Washington, DC: U.S. Department of the Interior, National Park Service, Technical Preservation Services, https://www.nps.gov/tps/standards/treatment-guidelines-2017.pdf.

HAER (Historic American Engineering Record). 1968. "U.S. Army Garrison Fort Ritchie, Upper Lake Dame, Fort Ritchie Military Reservation, Cascade, Washington County, MD.” HAER No. MD-104. Philadelphia, PA: HAER, National Park Service, Northeast Region, Philadelphia Support Office. LOC Call No. Library of Congress as HAER MD, 22-CASC,1-. https://www.loc.gov/item/md1387/.

Longe, T., J. Helstowski, R. Chuang, D. Johnston, G. McKown, K. Mason, R. Rikramanayake, and C. Troxell. 1998. Fort Ritchie Base Realignment and Closure (BRAC) Cleanup Plan (BCP), Version II. Aberdeen Proving Ground, MD: U.S. Army Environmental Center. https://apps.dtic.mil/dtic/tr/fulltext/u2/a348918.pdf.

Forest Fire Lookout Association. Undated. "Maryland Lookouts: Quirauk: Washington County.” Accessed 1/26/2018. https://easternuslookouts.weebly.com/quirauk.html.

Miller, John A. 2013. A Midnight Battle Along the Mason-Dixon Line: A Civil War 15o th Commemorative Handbook of the Battle of Monterey Pass. Chambersburg, PA: Franklin County Visitors Bureau.

NPS. 1997a. National Register Bulletin \#15: How to Apply the National Register Criteria for Evaluation. Washington, DC: U.S. Department of the Interior.

1997b. National Register Bulletin \#16A: How to Complete the National Register Registration Form. Washington, DC: U.S. Department of the Interior, National Park Service. 
. 1999. National Register Bulletin: How to Prepare National Historic Landmark Nominations. Washington, DC: U.S. Department of the Interior, National Park Service.

Rouse, Parke. 1995. The Great Wagon Road: From Philadelphia to the South. Richmond, VA: Dietz Press, 1995.

Sanders, Suzanne L., Katherine E. Grandine, Ellen Saint Onge, and Patrick Giglio. 1996. Archaeological and Architectural Investigations at Carlisle Barracks, Cumberland County, Pennsylvania. Report submitted to the U.S. Army Corps of Engineers, Baltimore District. Copies available from the Pennsylvania Historical and Museum Commission, Division of Archeology and Protection.

Schlotterbeck, Judith A. 1977. The Pen Mar Story. Funkstown, MD: Tri-State Printing, Inc.

Spitzer, Carroll F. 1986. A Pictorial History of Pen Mar Park. Hagerstown, MD: Tri-State Printing Co.

Strain, Paula M. 1993. The Blue Hills of Maryland: History Along the Appalachian Trail on South Mountain and the Catoctins. Vienna, VA: Potomac Appalachian Trail Club.

Taggart, Thomas, S. S. Downin, L. McKee, and C.G Robertson. 1859. A Map of Washington County Maryland. Map on file at Library of Congress, LOC control number 2002624033 .

Taylor, David L. 1999. Pen Mar Historic District. National Register of Historic Places Nomination Package. Generated by Taylor Associations Inc. and submitted to the Maryland Historic Trust, July 1999 https://msa.maryland.gov/megafile/msa/stagsere/se1/se5/022000/022700/022703/pdf/ msa_se5_22703.pdf.

“The Telephone News." 1911. Philadelphia, PA: the Bell Telephone Company of Pennsylvania.

USDA (U.S. Department of Agriculture). 2003. Soil Survey of Washington County, Maryland. College Park MD: University of Maryland Press.

USDA NRCS (U.S. Department of Agriculture, Natural Resources Conservation Service). 2018. "Web Soil Survey." https://websoilsurvey.nrcs.usda.gov/app/WebSoilSurvey.aspx.

USGS (US Geological Survey). 2016a. Maryland-Pennsylvania Hagerstown Quadrangle (1909). USGS Digital Raster Graphics, https://archive.usgs.gov/archive/sites/topomaps.usgs.gov/drg/index.html.

2016b. Smithburg MD-PA Quadrangle 71/2 minute series map. Prepared by U.S Department of Agriculture, Forest Service under direction of the Chief of Engineers, U.S. Army 1944, https://archive.usgs.gov/archive/sites/topomaps.usgs.gov/drg/index.html.

USGS (U.S. Department of the Interior Geologic Survey). 1909. Maryland-PennsylvaniaWest Virginia Hagerstown 30x6o Minute Quadrangle. Washington DC: Government Printing Office. 
. 1919. Maryland-Pennsylvania-West Virginia Hagerstown 30x6o Minute

Quadrangle. Washington DC: Government Printing Office.

. 1944. Maryland-Pennsylvania Smithsburg 7.5 Minute Quadrangle.

Washington DC: Government Printing Office.

. 1953. Maryland-Pennsylvania Smithsburg 7.5 Minute Quadrangle.

Washington DC: Government Printing Office.

1983. Maryland-Pennsylvania-West Virginia Hagerstown 30x6o Minute

Quadrangle. Washington DC: Government Printing Office.

Williams, Thomas J. C. 1906. A History of Washington County Maryland, from the Earliest Settlements to the Present Time: Including a History of Hagerstown, Vol 1. Hagerstown, MD: the Higginson Book Company.

\section{Uncited works}

Bloom, Robert L. 1992. A History of Adams County, Pennsylvania, 170o-19oo.

Gettysburg, PA: Adams County Historical Society.

Coddington, Edwin B. 1983. The Gettysburg Campaign: A Study in Command. Dayton $\mathrm{OH}$ : Morningside Bookshop.

Kline, Joel L. 1985. An Archaeological Overview and Management Plan for the Site R. Report submitted to the National Park Service, Philadelphia, PA.

Mason, Steven, Jonathan Schroeder, David Van Riper, and Steven Ruggles. 2018. "IPUMS National Historical Geographic Information System [Database]" Minneapolis: University of Minnesota. https://www.nhgis.org/.

Michels, Joseph W. 1968. "Settlement Pattern and Demography at Sheep Rock Shelter: Their Role in Cultural Contact" Southwestern Journal of Anthropology, 25(1):66-82. https://www.jstor.org/stable/3629302?seq=1\#metadata_info_tab_contents.

Small, D., and W. Wagner. 1821. Map of York and Adams Counties. York, PA: Small and Wagner.

\section{Archival resources}

\section{Blue Ridge Summit Free Library}

McClellon, John Howard. Undated. Blue Ridge Summit: the Beginnings of a Resort Area. Unpublished manuscript on file.

Collection of historic postcards of Pen Mar Park.

\section{Western Maryland Room, Hagerstown Free Library, Hagerstown MD.}

Ward, Harold L. 1962. Pen-Mar Park: The Gem of the Blue Ridge. Unpublished manuscript.

Collection of historic postcards and newspaper clippings on Pen Mar Park 


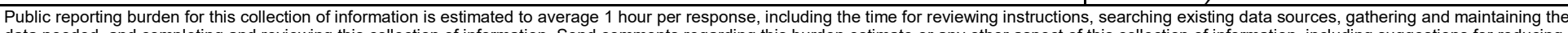

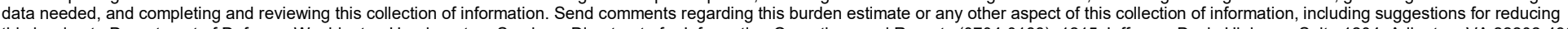

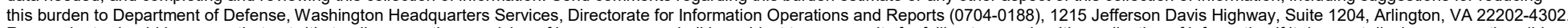

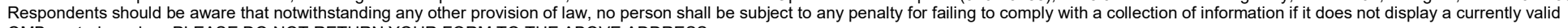
OMB control number. PLEASE DO NOT RETURN YOUR FORM TO THE ABOVE ADDRESS.
1. REPORT DATE (DD-MM-YYYY) 08/01/2019

\section{REPORT TYPE}
Final Technical Report (TR)

\section{TITLE AND SUBTITLE}

Raven Rock Mountain Complex Site C, MD Archaeological Phase I Survey

3. DATES COVERED (From - To)

5a. CONTRACT NUMBER

5b. GRANT NUMBER

5c. PROGRAM ELEMENT

5d. PROJECT NUMBER

Carey L. Baxter, Adam D. Smith, and Ellen R. Hartman

5e. TASK NUMBER

5f. WORK UNIT NUMBER

7. PERFORMING ORGANIZATION NAME(S) AND ADDRESS(ES)

U.S. Army Engineer Research and Development Center (ERDC)

Construction Engineering Research Laboratory (CERL)

2902 Newmark Dr

Champaign, IL 61824

\section{SPONSORING / MONITORING AGENCY NAME(S) AND ADDRESS(ES)}

Environmental Safety, Health, and Industrial Hygiene Department

Raven Rock Mountain Complex

Fairfield, PA 17320

\section{DISTRIBUTION / AVAILABILITY STATEMENT}

Approved for public release; distribution is unlimited.

\section{SUPPLEMENTARY NOTES}

This study was funded by Raven Rock Mountain Complex, under reimbursable Project 469449, "Work for RRMC."

\section{ABSTRACT}

The U.S. Congress codified the National Historic Preservation Act of 1966 (NHPA), the nation's most effective cultural resources legislation to date, mostly through establishing the National Register of Historic Places (NRHP). The NHPA requires federal agencies to address their cultural resources, which are defined as any prehistoric or historic district, site, building, structure, or object. Section 110 of the NHPA requires federal agencies to inventory and evaluate their cultural resources, and Section 106 requires them to determine the effect of federal undertakings on those potentially eligible for the NRHP.

In 2017, ERDC-CERL was tasked with conducting a Phase I Archaeological survey of Raven Rock Mountain Complex Site C in Maryland. RRMC is a division of the Washington Headquarters Service (WHS). No comprehensive Phase I Survey had been conducted at this site previously. This report documents that survey effort. In consultation with the Maryland State Historic Preservation Officer (SHPO), this work fulfills the Section 110 responsibilities for the archaeology at Site C.

\section{SUBJECT TERMS}

Archaeological site location, Historic preservation, Cultural property-Protection, Archaeology Military bases

16. SECURITY CLASSIFICATION OF:

\section{a. REPORT}

Unclassified

\section{b. ABSTRACT}

Unclassified

\section{LIMITATION} OF ABSTRACT

c. THIS PAGE

Unclassified
18. NUMBER OF PAGES

UU
PERFORMING ORGANIZATION REPORT

ERDC/CERL TR-19-9

10. SPONSOR/MONITOR'S ACRONYM(S)

1. SPONSOR/MONITOR'S REPORT NUMBER(S) 